\title{
Do Managers Trade on Public or Private Information? Evidence from Fundamental Valuations
}

\author{
David Veenman \\ Erasmus School of Economics - Erasmus University Rotterdam \\ dveenman@ese.eur.nl
}

March 2012

\begin{abstract}
Using accounting-based (residual income) valuations, this study examines the extent to which abnormal returns after insider share trades are explained by private information versus mispricing of public information. For a sample of insider trades in the Netherlands (19992008), I find that managers' share purchase decisions are associated with positive future abnormal returns as well as equity undervaluation. Even though undervaluation results in predictable price increases, positive abnormal returns following purchases persist after controlling for fundamental valuations. Thus, this study provides evidence on the sources of managers' personal trading gains and suggests that positive abnormal returns after insider share purchases reflect both private information and managers' responses to market mispricing of public information.
\end{abstract}

Keywords: insider trading; mispricing; residual income valuation; private information

\footnotetext{
This study is partly based on my dissertation completed at the University of Amsterdam. I appreciate the helpful comments and suggestions from an anonymous reviewer, Joost Impink, and Laurence van Lent (editor). I also thank seminar participants at the University of Amsterdam, the European Accounting Association annual meeting, and the Monash University PhD Accounting and Finance Symposium in Prato for helpful comments on earlier drafts.
} 


\section{Do Managers Trade on Public or Private Information? Evidence from Fundamental Valuations}

\section{Introduction}

Despite worldwide regulation, empirical evidence suggests that corporate insiders (i.e., officers and directors of publicly listed firms) earn abnormal returns when trading their firms' securities (Seyhun 1986; Pope et al. 1990; Betzer and Theissen 2009; Fidrmuc et al. 2011). While such abnormal returns are often interpreted as reflecting private information, a potential alternative explanation is that insiders have a superior ability in detecting deviations between market prices and firm fundamentals. In this study, I examine the extent to which abnormal returns following managers' share trades can be explained by private information versus the market mispricing of public information.

The study is motivated by evidence in the corporate finance literature, which suggests that managers have a superior ability to detect market mispricing. For example, prior research suggests that managers repurchase shares (Brav et al. 2005), issue new equity (Graham and Harvey 2001), or engage in takeovers (Dong et al. 2006) in response to mispricing. If managers also recognize and act on mispricing when trading firm shares on their personal accounts, trading in response to mispricing implies that insiders may earn abnormal returns without having access to private information. Identifying whether private information or mispricing of public information explains the abnormal returns after insider trades has important implications for securities regulation focused on deterring profitable trading on private information.

Extending managers' market timing ability to the context of insider trades, I predict that insiders' share purchases are associated with undervaluation and that share sales are associated with overvaluation. To assess the extent of over- or undervaluation of a firm's stock, I rely on a 
construct specifically designed to detect mispricing. That is, I compute fundamental value-toprice $(\mathrm{V} / \mathrm{P})$ ratios based on the residual income valuation (RIV) model and examine the association with managers' trading decisions. Following prior research (e.g., Frankel and Lee 1998; Barniv et al. 2010), I posit that firms with relatively high (low) V/P ratios are undervalued (overvalued), implying that high (low) V/P predicts positive (negative) future abnormal returns. After establishing whether insider trades are associated with mispricing, I analyze whether abnormal returns after insider trades are dampened after controlling for fundamental valuations.

Using a sample of trades conducted by corporate insiders in the Netherlands during the period 1999-2008, I first show that purchases of shares are associated with significantly positive future abnormal stock returns. Sales of shares are followed by negative, but insignificant, future abnormal returns. The positive abnormal returns after insider purchases accentuate for the subsample of smaller firms which potentially have greater information asymmetry and/or mispricing (i.e., when firms in the top quintile of firm size are excluded). ${ }^{1}$ Prior research has generally concluded that such abnormal returns reflect managers' private information advantage.

Next, I compute fundamental valuation ratios based on the RIV model for a sample of 9,441 firm-months. I find these ratios are significantly positively associated with future abnormal returns after controlling for a range of control variables (including indirect proxies for mispricing used in prior research). Then, if insiders are able to identify and respond to situations of market mispricing, I predict they are more likely to purchase (sell) shares in firms with relatively high (low) V/P. Consistent with this prediction, V/P is significantly higher in months when insiders buy and, to a lesser extent, lower in months when insiders sell their firms' shares. Hence,

\footnotetext{
${ }^{1}$ Smaller firms are likely associated with greater mispricing of public information due to greater market uncertainty about the implications of firm-specific information for future earnings and current value. For example, Zhang (2006) shows that smaller firms are associated with greater price drifts after information events, suggesting greater underreaction for firms with greater information uncertainty. Similary, evidence in the post-earnings announcement drift literature suggests that smaller firms are associated with greater underreaction (e.g., Bernard and Thomas 1989) and, hence, more mispricing of public earnings information.
} 
insiders' trading in response to mispricing - which results in predictable price reversals potentially explains an important component of abnormal returns after insider trades.

I then examine the association between insider trades and future returns after controlling for fundamental valuations and a set of control variables. If abnormal returns after insider trades are fully explained by trading on mispricing, the association between trading and future returns should disappear after controlling for V/P. On the other hand, if insiders trade on private information in addition to trading on mispricing, the association with future returns is expected to persist after controlling for V/P. I find that even though insiders purchase when V/P is high and $\mathrm{V} / \mathrm{P}$ is associated with future abnormal returns, abnormal returns after insider purchases persist. Comparing results for the full sample of firms versus the sub-sample of smaller firms, I find that the incremental abnormal returns after purchases in smaller firms are most likely driven by increased private information. Results are robust to estimating firm-specific time series regressions in which the firm acts as its own control.

Overall, I conclude that insiders' trading decisions are at least in part motivated by temporary deviations between market prices and firm fundamentals. Although such trading contributes to the abnormal returns following managers' trades, managers' share purchases are associated with abnormal returns even after controlling for mispricing. Hence, private information remains an important driver of insiders' purchase decisions. Whether such trading is harmful depends on one's views on the desirability of insider trades. While some argue insider trading is unfair and harms investor confidence (e.g., Fishman and Hagerty 1990), others argue that insider purchase decisions may provide important private information signals to investors (e.g., Manne 1966). ${ }^{2}$ My

\footnotetext{
${ }^{2}$ Jeng et al. (2003) find that, even though U.S. insiders earn significant abnormal returns on their share purchases, the expected costs to shareholders of trading against informed insiders are relatively low at 10 cents per $\$ 10,000$ transaction. They argue that outside investors (p. 455) "have little to fear from these reported transactions, because insider trades make up but a tiny portion of the market." Hence, the benefits of allowing corporate insiders to trade
} 
findings suggest that in addition to signaling private information, disclosures of insiders' share purchases are likely to signal relative undervaluation of a firm's stock.

This study is most closely related to Piotroski and Roulstone (2005). They conclude that “insiders capitalize on both outside investors' valuation errors and their own superior private information when making their trading decisions", but that "trading on the basis of superior knowledge is less important than trading on the basis of misvaluation/contrarian beliefs" (p.66). My study differs in two major respects. First, their inferences are based on prior returns and book-to-market $(\mathrm{B} / \mathrm{P})$ ratios as proxies for mispricing and therefore subject to feasible alternative explanations (Dong et al. 2006; Ali et al. 2011). ${ }^{3}$ Instead, I examine the association of managers' trading decisions with a construct specifically designed to detect mispricing. Second, I examine the implications of mispricing for the profitability of insiders' trades. The focus on fundamental valuations allows me to better identify the portion of trading gains that is explained by managers' private information and the future returns that are not explained by current mispricing. ${ }^{4}$

This study makes the following contributions. First, while an extensive body of literature documents abnormal returns after insider trades for U.S. and international samples, there is limited evidence on the sources of such returns. Identification of the sources of insider trading gains is constrained by the difficulty of capturing managers' actual private information. This study recognizes that abnormal returns after insider trades not necessarily indicate private information. Instead, abnormal returns can reflect i) insiders recognizing mispricing, and ii) the

their firms' shares, and convey their private information to the market, may outweigh the relatively low costs to outside investors.

${ }^{3}$ See section 3 for further discussion on the alternative interpretations of variation in $\mathrm{B} / \mathrm{P}$ ratios and prior returns.

${ }^{4}$ Rozeff and Zaman (1998) and Jenter (2005) also examine the association of insider trades with prior returns and $\mathrm{B} / \mathrm{P}$ ratios. Other studies have examined specific situations in which insider trades are driven by market mispricing. For example, Ali et al. (2011) find that U.S. insiders respond to mispricing resulting from price pressure induced by mutual funds. Kolasinski and Li (2010) show that U.S. insiders benefit from investor underreaction to earnings announcements, while Core et al. (2006) find U.S. insider trading activity to be associated with trading strategies based on the accrual anomaly. In contrast to these studies, I focus on the effect of mispricing on insider trading in general and further identify the implications of this effect for the abnormal returns after average insider trades. 
market subsequently reversing the mispricing. Relying on accounting-based (residual income) valuation estimates, I isolate managers' private information by identifying the portion of abnormal returns that is not explained by fundamental valuations (i.e., mispricing) and show that - on average - abnormal returns are explained by private information as well as mispricing. These findings have implications for studies focused on disclosures of insider trades (e.g., Brochet 2010), since these disclosures may signal both private and public information.

Second, a distinctive feature of this study is that it develops a research design that allows one to disentangle private information versus mispricing explanations in settings where market trading activities are associated with subsequent abnormal stock returns. While this study analyzes insider trades, examples of alternative settings - where managers are directly involved are corporate share repurchases, seasoned equity offerings, stock option grants, or M\&A activities. In contrast to the insider trading literature that generally interprets abnormal returns as reflecting private information, the literature on corporate trading activities generally associates corporate trading activity with mispricing (e.g., Grullon and Ikenberry 2000; Baker and Wurgler 2002; Jenter 2005). Future studies may examine the extent to which managers use their private information (versus responding to mispricing) in corporate financing decisions using accountingbased fundamental valuation ratios.

Lastly, the evidence in additional tests of this study adds to a small body of work applying the Abnormal Earnings Growth (AEG) model (Ohlson and Juettner-Nauroth 2005) in a fundamental valuation context (Penman 2005; Brief 2007). Specifically, while I find the association between fundamental valuations and insider trading is not robust to using AEG as alternative valuation model, I find this is most likely driven by the inability of AEG to detect mispriced securities. The finding that value-to-price ratios based on AEG are not associated with future stock returns adds 
to recent evidence suggesting that RIV estimations better approximate market prices compared to AEG (Jorgensen et al. 2011).

This study proceeds as follows. Section 2 presents background literature, institutional setting, and hypothesis development. Section 3 highlights key issues related to the identification of mispricing and the choice of an appropriate valuation model. Section 4 presents the research design, Section 5 presents the main results, and Section 6 presents additional analyses. Section 7 concludes the study.

\section{Background and hypotheses}

\subsection{Insider trades and future abnormal returns}

Prior research on insider trading has generally focused on the U.S. and, to a lesser extent, the U.K. The consensus of this research is that insiders earn abnormal returns when trading their own firms' securities (Seyhun 1986; Pope et al. 1990; Seyhun 1998; Lakonishok and Lee 2001; Friederich et al. 2002) and that disclosures of such transactions trigger strong price reactions (Fidrmuc et al. 2006; Brochet 2010; Veenman 2012). These findings appear to be driven by insiders' purchases, given that sales are more likely driven by consumption and diversification motives (Ofek and Yermack 2000; Lakonishok and Lee 2001; Jeng et al. 2003).

Recent studies extend the literature to the continental European setting. In contrast to the U.S. and U.K., many European countries did not have well established rules and enforcement regarding corporate insider trading until the mid-1990s (Bhattacharya and Daouk 2002). For example, Germany only formally prohibited trading on private information in 1994 and did not require any public disclosure of transactions until July 2002 (Betzer and Theissen 2009). The Market Abuse Directives (MAD), introduced in 2003 and implemented in most countries by the 
end of 2005, harmonized EU insider trading rules. Christensen et al. (2011) present evidence suggesting the implementation of MAD is associated with increased market liquidity.

Recent evidence for continental Europe is consistent with that for the U.S. and U.K. Fidrmuc et al. (2011) examine insider trades in 15 countries and find that, particularly in better shareholder protection countries, insider share purchases are associated with significantly positive future abnormal returns. Dardas and Guttler (2011) find significant stock price reactions around disclosures of trades in four European countries. Betzer and Theissen (2009) show that German insider trades are associated with future abnormal returns. Comparable evidence is found for countries such as Switzerland (Zingg et al. 2007) and Sweden (Kallunki et al. 2009). For the Netherlands, Degryse et al. (2009) find that insider purchases are associated with significantly positive abnormal returns. Cziraki et al. (2011) find that abnormal returns after trades are affected by anti-shareholder (corporate governance) mechanisms.

Regarding the source of insiders' information advantage, U.S. based evidence suggests that insider trades are associated with future cash flow (earnings) news. Piotroski and Roulstone (2005) find an association between net insider trades and future earnings changes. Ke et al. (2003) show that insiders sell shares in anticipation of long-term future earnings declines. In addition, some insiders contribute to their own private information advantage by managing accruals (e.g., Bartov and Mohanram 2004). Hence, knowledge of future earnings performance is one potential source of insiders' abnormal returns. Other studies find that insiders' asymmetric information advantage increases with the firm's R\&D intensity (Aboody and Lev 2000), low analyst following (Frankel and Li 2004), low quality financial reporting (Skaife et al. 2011), and low corporate governance (Jagolinzer et al. 2011). ${ }^{5}$

\footnotetext{
${ }^{5}$ The studies in this section focus on general associations between information and insider trades. Other studies have focused on specific settings such as earnings announcements (Sivakumar and Waymire 1994), management forecasts
} 


\subsection{Hypotheses}

An alternative explanation for predictable returns after insider trades is that managers are able to recognize pricing errors that will reverse in the future. For example, Grullon and Ikenberry (2000, p.36) argue that, in the context of share repurchases, "with their fundamental understanding of the firm and its industry, a firm's managers are perhaps best positioned to recognize when market prices diverge from their true value". Evidence of predictable returns after repurchases and seasoned equity offerings is often interpreted as managers responding to perceived market mispricing (e.g., Jenter 2005). Baker and Wurgler (2002) find that firms' current capital structures are determined by past market timing decisions, while Dong et al. (2006) show that mispricing affects takeover decisions. Brav et al. (2005, p.514) find that "[a]bout one-half of the interviewed CFOs say that their firm tracks repurchase timing and that their firm can beat the market, some say by $\$ 1$ or $\$ 2$ per share over the course of the year". Survey evidence by Graham and Harvey (2001) further suggests that managers view recent stock price appreciation as an important factor in their equity issuance decisions.

The above discussion implies that managers recognize and act on temporary deviations between stock price and fundamental value. In this study, I predict that managers similarly time their personal insider trades in response to market mispricing. This is because trading on (and profiting from) mispricing is likely less costly for managers compared to trading on a specific private information advantage due to the lower risk of litigation. ${ }^{6}$ Accordingly, I formulate the following "mispricing hypothesis", stated in alternative form:

(Cheng and Lo 2006), annual/interim report filings (Huddart et al. 2007), restatements (Badertscher et al. 2011), bankruptcies (Seyhun and Bradley 1997) or mergers and acquisitions (Seyhun 1990). My study focuses on average insider trading behavior.

${ }^{6}$ This comparison is analogous to comparisons between "active" and "passive" insider trading (e.g., Huddart et al. 2007). When in possession of private information, passively delaying purchases (sales) after bad (news) events is ex ante less costly for a manager compared to actively purchasing (selling) before good news (bad news) events, due to the lower risk of litigation. 
H1: Insiders are more likely to purchase (sell) shares when their firms' equity is undervalued (overvalued) by the market.

To the extent that mispricing is corrected at some point in time, deviations between prices and fundamentals should predict future abnormal price movements. Specifically, if we defined the difference between price $(P)$ and fundamental value $\left(V^{*}\right)$ as the degree of overvaluation (positive $P-V^{*}$ ) or undervaluation (negative $P-V^{*}$ ) and such mispricing is reversed within $\tau$ units of time, the expected return over the period equals:

$$
E_{t}\left[R_{t, t+\tau}\right]=\frac{V_{t}^{*}-P_{t}}{P_{t}}+R R_{t}
$$

Where $R R$ is the required rate of return (cost of equity capital) adjusted for time period $\tau$. Equation (1) implies that relatively high (low) ratios of fundamental value to stock price $\left(V^{*} / P\right)$ are associated with positive (negative) future abnormal returns when prices correct for undervaluation (overvaluation). Hence, if managers respond to mispricing, abnormal returns after insider trades are potentially explained the reversal of prior mispricing. This alternative explanation allows for abnormal returns in the absence of a private information advantage. To test the private information versus mispricing explanations, I formulate the following hypothesis, again stated in alternative form:

H2: Insider purchases (sales) are associated with positive (negative) future abnormal returns after controlling for mispricing.

If $\mathrm{H} 2$ is supported, I conclude that abnormal returns after insider trades are driven by insiders' private information in addition to their potential response to the mispricing of public information. 


\subsection{Insider trading regulation regulation in the Netherlands}

Although it is beyond the scope of this study to comprehensively analyze institutional and legal differences across countries, it is important to highlight the differences and similarities between the U.S. and Dutch institutional settings in the context of corporate insider trades. Because the vast majority of prior insider trading research has been conducted on U.S. data, this comparison helps to better understand how my study fits into the broader literature. ${ }^{7}$

In the U.S., Rule 10b-5 under section 10(b) of the Securities and Exchange Act of 1934 prohibits the trading of the securities of any issuer on the basis of private information. Private information is defined as "material nonpublic" information, i.e., information that will move a security's price when made public. While section 10(b) applies to anyone, section 16(a) defines corporate insiders more formally as officers, directors, and large shareholders of more than ten percent of the equity of a company. These insiders are required to report transactions in the issuer's securities to the Securities and Exchange Commission (SEC) within two business days.

Dutch insider trading rules and definitions largely mirror those of the U.S. In the Netherlands, the Netherlands Authority for the Financial Markets (AFM) conducts the oversight on stock market integrity and disclosures of price-sensitive information. As a result of European harmonization, the Market Abuse Directive (MAD) was implemented in the Netherlands in October 2005. MAD resulted in increased penalties and restrictions on market abuse in order to protect market integrity.

Similar to the U.S., initially anyone in possession of private information is prohibited from trading on this information under the Dutch law. As a result of the introduction of MAD, this rule has been replaced for a narrower rule that focuses on primary insiders that have a link with the

\footnotetext{
${ }^{7}$ For a comprehensive comparative legal analysis on insider trading in the U.K., Germany, France, Spain and the Netherlands, and the role of European harmonization, see Welch et al. (2005).
} 
issuer (Welch et al. 2005). Secondary insiders, however, are still prohibited from knowingly trading on private information. ${ }^{8}$ As in the U.S. definition, private information entails information that has not been made public and that could reasonably be expected to have "an effect" on security prices when publicized. After the introduction of MAD, the term "a significant effect" was introduced, thereby converging to the term "material" used in the U.S..

Before introduction of MAD, rule 46b of the Wet Toezicht Effectenverkeer (Wte) 1995 required that registered corporate insiders publicly disclose transactions in an issuer's securities before the tenth day of the following month. ${ }^{9}$ After MAD, Wte rule $46 \mathrm{~b}$ was replaced by Wte rule 47a. In January 2007, Wte 1995 was incorporated into the Wet Financieel Toezicht (Wft) 2006 and public disclosure of insiders' trades is currently governed in Wft rule 5:60. Corporate insiders, required to report their trading activity within five business days, are defined as all persons involved in policy making and supervision, other employees with reasonable access to price sensitive information, and large "qualified" holders of shares with an ownership of $10 \%$ or more in the issuing company. ${ }^{10}$ Hence, the definition of corporate insiders largely mirrors that of the U.S. corporate insiders.

An important difference between the U.S. and the Netherlands concerns the U.S. "shortswing" rule under section 16(b) of the Exchange Act. This rule prevents short-term trading opportunities to insiders by allowing shareholders to recover profits made by purchasing and selling (or selling and purchasing) within a period of six months. Hence, it is not possible for

\footnotetext{
${ }^{8}$ For primary insiders, who by virtue of their relation with the issuer are privy to private information, the legal question of whether these persons knew or should have reasonably known that they possessed private information when trading is not relevant (AFM 2010).

${ }^{9}$ Prior to the Sarbanes-Oxley Act of 2002 (SOX), the reporting deadline for U.S. insider transactions was also equal to the tenth day of the month following the trading.

${ }^{10}$ Reporting of insider trades is timely in both settings, although transactions are slightly more timely in the U.S. (two business days) versus the Netherlands (five business days). An other minor difference is that since 2002, Dutch "top executives" are required to report their transactions as soon as possible, "without delay" (Degryse et al. 2009). Given the focus of my study on long-run returns after insider trades, this difference in reporting timeliness is unlikely to affect the generalizability of my results.
} 
insiders to make round-trip trades in periods of six months or less. This rule potentially affects the nature of information contained in insiders' trading decisions in the U.S. versus the Netherlands, as no such rule exists in the Dutch setting. Then, if Dutch insiders trade on private information and make abnormal returns on their trades, they are more likely to gain from trading on private information that materializes within six months compared to U.S. insiders. This has potential implications for the horizon over which insiders' abnormal returns are realized.

An other important difference is that, in the Netherlands, trading is prohibited in the two months preceding material events, such as the annual earnings announcement, by a Model Code introduced in 1987 (see also Kabir and Vermaelen 1996). This is similar to restrictions imposed by the LSE Model Code in the U.K. In the U.S., on the other hand, such "blackout periods" are not mandated by law. However, this difference in regulation is unlikely to affect empirical studies to an important extent, given that many U.S. companies adopt trading bans voluntarily (Bettis et al. 2000).

Overall, I conclude that the institutional setting concerning corporate insider trades in the Netherlands is quite similar to that in the U.S. ${ }^{11}$ The most important difference in rules is the U.S. short-swing rule which potentially results in abnormal returns after insider trades that are realized over longer horizons compared to the Dutch setting.

Of course, similar rules do not necessarily imply similar levels of information based trading, as enforcement also affects insiders' expected costs of trading on private information. Although it is difficult to compare frequencies of insider trading cases due to differences in scale of the two markets, Cziraki et al. (2011) report that the AFM actively monitors insider trading activity. This results in several prosecutions and administrative proceedings per year. Further, based on the

\footnotetext{
${ }^{11}$ Degryse et al. (2009, p.11) also posit that "[t]he principles of law concerning insider trading are similar to those found in the U.S. or in the U.K."
} 
legal enforcement indices reported by La Porta et al. (1998), one could conclude that enforcement in the U.S. and the Netherlands is at the similar, high level. Nevertheless, an extension of this study to the U.S. or a cross-country setting would potentially be interesting when specific predictions on the costs and benefits of trading on private versus public information can be formulated. This is beyond the scope of my study.

\section{Mispricing and fundamental valuation models}

\subsection{Fundamental valuations versus prior returns and B/P ratios}

Rozeff and Zaman (1998), Jenter (2005), and Piotroski and Roulstone (2005) analyze the association of insider trades with prior stock returns and $\mathrm{B} / \mathrm{P}$ ratios as proxies for mispricing. As explained below, the book-to-market ratio is a noisy proxy for mispricing leading to feasible alternative explanations (see also Ali et al. 2011). Similarly, prior returns do not reflect mispricing if price changes simply capture changes in firm and market fundamentals. While managers are generally overinvested in their firm's equity, they are likely to have increased incentives to diversify and liquidate their holdings when prices rise (e.g., Ofek and Yermack 2000). In contrast to managers' trading in response to mispricing, such trading does not imply predictable future price changes.

The Residual Income Valuation (RIV) model assists in clarifying the difference between fundamental valuations and $\mathrm{B} / \mathrm{P}$ ratios in a mispricing context. Under the no-arbitrage assumption, fundamental value $\left(V^{*}\right)$ equals the present value of expected future dividends in the Dividend Discount Model (DDM). With the additional assumption of clean surplus accounting, 
the DDM can be rewritten in terms of accounting numbers with the RIV formula (Edwards and Bell 1961; Peasnell; 1982; Ohlson 1995): ${ }^{12}$

$$
V_{t}^{*}=b v_{t}+\sum_{i=1}^{\infty} \frac{E_{t}\left[x_{t+i}-r_{e} b v_{t+i-1}\right]}{\left(1+r_{e}\right)^{i}}=b v_{t}+\sum_{i=1}^{\infty} \frac{E_{t}\left[r i_{t+1}\right]}{\left(1+r_{e}\right)^{i}}
$$

where $b v_{t}$ is the book value of equity per share at time $t, r_{e}$ is the cost of equity capital, $x_{t+i}$ is net income per share in period $t+i$, and $r i_{t+i}$ is residual income per share in period $t+i\left(x_{t+i}-r_{e} b v_{t+i-1}\right.$ ). Equation (2) suggests that fundamental value equals the sum of current equity value in the balance sheet and the present value of the stream of expected future residual income.

Defining "relative valuation" by the ratio of fundamental value to the observed market price $\left(V^{*} / P\right)$, it can be shown that relative valuation is a combination of the book-to-market (book value-to-price) ratio and the price-scaled present value of expected future residual income ( $p v r i)$.

$$
\frac{V_{t}^{*}}{P_{t}}=\frac{b v_{t}}{P_{t}}+\frac{\sum_{i=1}^{\infty} \frac{E_{t}\left[x_{t+i}-r_{e} b v_{t+i-1}\right]}{\left(1+r_{e}\right)^{i}}}{P_{t}}=\frac{b v_{t}}{P_{t}}+\frac{p v r i_{t}}{P_{t}}
$$

Equation (3) highlights the important difference between book-to-market ratios and fundamental value-to-price ratios. $V^{*} / P$ equals the book-to-market ratio only if a firm earns a return on equity equal to its cost of capital, but differs from the book-to-market ratio if it earns positive or negative future residual income (pvri). While prior studies testing the mispricing hypothesis for insider trades rely on B/P ratios as proxy for mispricing (e.g., Jenter 2005), the literature has interpreted $\mathrm{B} / \mathrm{P}$ ratios in a variety of ways. In addition to proxying for mispricing, $\mathrm{B} / \mathrm{P}$ ratios have been interpreted as proxies for priced risk (Fama and French 1992; Ali et al. 2003), conservative

\footnotetext{
12 Clean surplus accounting requires that all changes in shareholders' equity, apart from transactions with shareholders (dividends, share issues, or repurchases) flow through the income statement. Other comprehensive income or "dirty surplus" items, which are directly recognized in equity without affecting net income, violate this requirement.
} 
accounting (Beaver and Ryan 2005; Roychowdhury and Watts 2007), or growth expectations (Skinner and Sloan 2002).

In contrast, relative valuations $\left(V^{*} / P\right)$ based on a fundamental valuation formula, such as RIV, conceptually only capture mispricing. To illustrate the difference, a low book-to-market ratio may reflect the conservative accounting treatment of research and development outlays for a pharmaceutical firm even though the firm can be undervalued by the market (high $V^{*} / P$ ). Relative valuations based on a fundamental valuation formula such as equation (3) correct for the ambiguity in book-to-market ratios as proxy for mispricing. In addition, valuation models such as RIV are not sensitive to conservative or aggressive accounting treatments (Palepu et al. 2007) as relatively low (high) book values result in relatively high (low) levels of future residual income. Similarly, valuation models such as RIV incorporate expected future growth in fundamentals that is not reflected in current book values. Thus, while $V^{*} / P$ ratios allow for direct testing of a mispricing hypothesis, book-to-market ratios capture mispricing with noise. ${ }^{13}$

\subsection{Choosing a fundamental valuation model}

The choice of the valuation model for calculating V/P ratios is a practical issue. Theoretically, valuations based on models such as the DDM, RIV, Discounted Cash Flow (DCF), or Abnormal Earnings Growth (AEG) model should be similar when forecasts are made over infinite horizons (e.g., Lundholm and O'Keefe 2001). In practice, however, valuations vary due to the need for forecasts over finite horizons (e.g., Penman 2001). The usefulness of a valuation model in practice is determined by the power of its finite horizon implementation. ${ }^{14}$

\footnotetext{
${ }^{13}$ Frankel and Lee (1998) and Ali et al. (2003) show that V/P ratios based on the RIV model predict future abnormal stock returns over and above B/P ratios. Given that B/P ratios are embedded in V/P ratios (Ali et al. 2003), this evidence can be interpreted as the superior ability of RIV model based valuations to identify market mispricing.

${ }^{14}$ In addition, one could argue that the practical power of RIV depends on the validity of the clean surplus assumption. However, it is unclear to what extent violations of clean surplus bias valuations in practice. Specifically, the randomness and transitory nature of most dirty surplus items (e.g., foreign currency translations) suggests these
} 
Finite versions of valuation models are needed because it is not possible to project the valuation attribute of a particular model (dividends, earnings, or free cash flows) into infinity. The valuation model is split up into a finite forecast horizon and a terminal value component. Over the finite forecast horizon, explicit forecasts of the valuation attribute are made for each unit of time. Next, simplifying and subjective assumptions are made regarding future growth in the valuation attribute beyond the finite forecast horizon. Two important aspects help RIV to become a more powerful tool for valuation compared to DDM or the DCF model.

First, while DDM and DCF are solely determined by discounted projections of future valuation attributes, RIV is "anchored" on the book value of equity. As a result, valuations are influenced to a smaller extent by subjective projections and assumptions. In fact, for some firms equity book value is already a close approximation of its fundamental value, therefore requiring limited additional speculation into the valuation equation (Penman 2005). Second, valuation models differ in the extent to which information on valuation attributes is available. In general, analysts forecast earnings and these forecasts are widely available. Also, for firms not paying dividends, the DDM valuation is solely determined by the terminal value; a discounted target price estimate. Hence, the use of book equity as an anchor and the use of earnings as the valuation attribute are important benefits that potentially make RIV a more useful valuation tool.

Empirical studies confirm the superiority of RIV in approximating fundamental values (Penman and Sougiannis 1998; Francis et al. 2000; Jiang and Lee 2005). ${ }^{15}$ Also, several studies

\footnotetext{
items should not matter in expectation (Penman 2001). In this regard, Isidro et al. (2006) find only weak empirical evidence of an association between dirty surplus items and valuation errors based on RIV for the U.S., while they find no association for samples based on France, Germany, or U.K. firms. Hence, even though clean surplus is often violated, such violation appears to have limited effects on practical valuations based on RIV.

${ }^{15}$ Penman and Sougiannis (1998) and Francis et al. (2000) show that practical implementations of RIV outperform DCF and DDM valuations. Assuming an efficient market, they find that RIV valuations are associated with lower valuation errors and explain more variation in prices than valuations based on the other models. Jiang and Lee (2005) test the dynamic stock price implications of RIV versus DDM and find that book values and earnings in RIV contain more useful information for equity valuation than dividends in DDM alone.
} 
find empirical evidence supporting RIV as a tool for the identification of mispricing (Frankel and Lee 1998; Lee et al. 1999; Barniv et al. 2010), thereby making RIV a suitable valuation model for the purpose of my study. ${ }^{16}$

Similar to RIV, the AEG valuation model is derived from the DDM: ${ }^{17}$

$$
V_{t}=\frac{e p s_{t+1}}{r_{e}}+\frac{1}{r_{e}} \sum_{\tau=2}^{\infty}\left[\frac{a g r_{t+\tau}}{\left(1+r_{e}\right)^{\tau-1}}\right],
$$

where $a g r_{t}$ is abnormal growth in earnings, defined as the difference between year $t$ cumdividend earnings and the expected earnings given earnings in year $t$ - 1 , i.e., $a g r_{t}=\left(e p s_{t}-r_{e} d p s_{t-1}\right)-\left(1+r_{e}\right) e p s_{t-1}($ Easton 2004)

Compared to RIV, the main advantage of AEG is that it does not rely on the clean surplus assumption. Given $i$ ) the common violation of clean surplus in practice and $i$ ) because clean surplus does not hold on a per-share basis when anticipated transactions with shareholders are nonzero (Ohlson 2005), the AEG model has been argued to have important advantages over RIV. In addition, analysts forecast earnings, not residual income. AEG therefore provides a more direct link between the attribute forecasted by analysts and its use in valuation (Penman 2005).

However, it is unclear to what extent these conceptual advantages make AEG a more useful valuation model in practice. In contrast to RIV, which relies on equity book value as anchor, AEG initializes on a forward-looking and speculative anchor (Penman 2005). Although equity book value is a noisy approximation of shareholder value (as discussed in the previous section), it

\footnotetext{
${ }^{16}$ While relaxing the market efficiency assumption, Frankel and Lee (1998) find that V/P ratios based on RIV are cross-sectionally associated with future abnormal stock returns. This finding suggests that the relative magnitude of a V/P ratio based on RIV is indicatice of the extent to which a firm is under- or overpriced by the market at a specific point in time. Barniv et al. (2010) present evidence suggesting RIV can also be used to identify mispriced securities in international settings. Lee et al. (1999) show that the time series of aggregate Dow 30 RIV valuations is cointegrated with index levels and that value-to-price ratios based on RIV are associated with future market returns. Overall, these findings suggest valuations based on RIV can be used to detect instances of mispricing.

${ }^{17}$ See Easton (2004) for an intuitive derivation of this model. See Ohlson and Juettner-Nauroth (2005), Ohlson (2005), Penman (2005), and Brief (2007) for more theory and discussions on the benefits and drawbacks of the model.
} 
can be argued to be a more objective starting point than capitalized expected earnings. The denominator in the capitalized earnings term further exacerbates this problem. To the extent that the discount rate $\left(r_{e}\right)$ is measured with error, the capitalized earnings term $\left(e p s_{t+1} / r_{e}\right)$ can be seriously biased. $^{18}$

Evidence on the practical usefulness of AEG versus RIV is limited, but points to RIV as producing more accurate approximations of prevailing market prices (Penman 2005; Jorgenson et al. 2011). ${ }^{19}$ Combined with the lack of existing evidence supporting the use of AEG in the identification of mispriced securities, I choose to focus on RIV as the main valuation model. In section 6.2, however, I return to AEG and test the extent to which it can be used to detect mispricing in general and in the specific context of my study.

\section{Research design}

Motivated by the availability of analyst forecasts of earnings, I use a forecast horizon of three years for the finite version of the RIV model as introduced in equation (2). After the forecast horizon of three years, residual income is assumed to grow at the average rate of $g$ in perpetuity:

$$
V_{o}=b v_{0}+\frac{r i_{1}}{\left(1+r_{e}\right)}+\frac{r i_{2}}{\left(1+r_{e}\right)^{2}}+\frac{r i_{3}}{\left(1+r_{e}\right)^{3}}+\frac{r i_{3}(1+g)}{(r-g)\left(1+r_{e}\right)^{3}}
$$

For every firm-month with sufficient data, I approximate the per-share value of equity $V$ using (5). Following Penman (2005), I set the cost of equity and growth rate parameters equal to $10 \%$ and 4\%, respectively, for all firms. Prior research suggests that alternative (firm-specific) parameters have little consequences in settings where one is interested in cross-sectional variation

\footnotetext{
${ }^{18}$ Penman (2005, p.376) argues that "despite decades of endeavor in research in finance, we do not know how to estimate the cost of capital that features in both RIV and AEG formulas. To be honest, it is a speculation and fundamental analysts warn of building speculation into a valuation. A method that puts less weight on this speculative component is to be preferred, all else equal. Of the two, the AEG valuation is more subject to this criticism."

${ }^{19}$ Penman (2005) presents descriptive evidence suggesting that valuations based on AEG are less accurate and more volatile compared to valuations based on RIV. Jorgenson et al. (2011) find similar results while varying assumptions and forecast horizons.
} 
in relative valuations (e.g., Frankel and Lee 1998; Sougiannis and Yaekura 2001). ${ }^{20}$ I compute fundamental value-to-price (V/P) ratios by scaling the monthly estimate of fundamental value per share by the market price $P$ in the same month. When $\mathrm{V} / \mathrm{P}$ is high relative to other firms in the same month, the stock is assumed to be undervalued, while it is assumed to be overvalued for relatively low values of V/P (Frankel and Lee 1998; Bradshaw 2004; Barniv et al. 2010).

For $b v$ at time 0 , I use the book value of equity from the most recent fiscal year for which earnings have been announced, scaled by shares outstanding. ${ }^{21}$ The calculations of expected residual income in years 2 and 3 require estimates of book values in years 1 and 2, respectively. The clean-surplus relation is applied with an assumption of a constant dividend $(d)$ payout ratio to derive expected book values as follows:

$$
b v_{1}=b v_{0}+x_{1}-d_{1}=b v_{0}+(1-k) x_{1}
$$

In a similar vein, book value in year 2 is derived from expected book value in year 1 , expected earnings in year 2 , and the dividend payout ratio $(k)$. The dividend payout ratio is assumed constant over time and is computed from the most recent financial statements. In case of negative earnings, the ratio is calculated as $d_{0} /\left[0.06 *\right.$ assets $\left._{0}\right]$ (Lee et al. 1999). In case $k>1$, the average payout from the most recent three years is used. Lastly, $k$ is winsorized at 0.5 (Jorgensen et al. 2011).

\footnotetext{
${ }^{20}$ All results presented in this study are qualitatively highly similar when using alternative rates for cost of equity and/or growth and using firm-specific discount rates based on CAPM.

${ }^{21}$ Although book value of equity data may not be available to the market at the time of the earnings announcement, results are qualitatively similar when using "synthetic" book values as in Lee and Swaminathan (1999) or when book value is assumed to be available to the market four months after fiscal year end.
} 


\subsection{Data}

The main tests compare insider trading firm-months to firm-months without insider trades. Therefore, I use the largest sample of firm-months available for Dutch listed firms. Table 1 outlines the sample selection procedure. For the period from April 1999 through December 2008 (consistent with the insider trading sample described in the next section) I identify 14,397 firmmonths in the intersection of COMPUSTAT Global and I/B/E/S, for 210 distinct firms. Next, I drop 218 observations with no one- and two-year ahead median EPS forecast. For the calculation of three-year ahead residual income I require either a three-year ahead EPS forecast or a forecast of the long-term growth rate in EPS. This results in the deletion of 867 observations.

- Insert Table 1 about here -

The largest drop in observations $(2,188)$ is due to lack of equity book value data on COMPUSTAT. Next, 101 observations are eliminated due to negative equity book values (Frankel and Lee 1998). I further delete 159 observations with missing stock price on I/B/E/S and 119 observations with stock price below $€ 1$ to preclude extreme ratios due to small denominators. Another 772 observations lack data for control variables, while 532 observations lack data to compute buy-and-hold returns for the 12-month period starting in the month after measurement of V/P. This results in a final sample of 9,441 firm-month observations for 156 firms.

\subsection{Insider trading data}

Insider transactions are collected from the AFM. Table 2 presents the construction of the insider transaction sample. Initially, 18,364 records are identified in the AFM online register for the period starting April 1999 and ending December 2008. Many individual trades are reflected in 
multiple records in the AFM register. ${ }^{22}$ Hence, the actual number of trades is substantially lower than 18,364. I eliminate 583 records for firms not available on COMPUSTAT, 1,733 records of firms not listed in Amsterdam, 5,867 records related to corporate financing transactions ${ }^{23}$, 1,672 records related to transactions in irregular instruments, and 1,367 records related to option grants or other transactions in options. The final sample of 7,142 records reflects 137 distinct firms.

\section{- Insert Table 2 about here -}

After careful examination of the data, aggregating multiple trades by firm-day, and requiring short-term stock return data around the transaction date, I identify 708 firm-days with purchase transactions and 1,477 days with sales transactions. The 1,477 sales firm-days include sales resulting from the liquidation of stock options. Following prior research, purchases only include open market purchases and do not include purchases through conversions of options (e.g., Cheng and Lo 2006; Huddart et al. 2007). The 708 purchase and 1,477 sales firm-days correspond to 533 purchase and 844 sales firm-months, respectively. After matching these firm-months with the sample of firm-months having V/P ratio data, 259 and 560 firm-months remain, respectively.

\subsection{Descriptive evidence on the abnormal returns after insider trades}

Although concurrent studies have identified the predictive ability of Dutch insiders' trades with respect to future stock returns (Degryse et al. 2009; Cziraki et al. 2011), the sample period and data filtering procedure differ in this study. Therefore, to assess the usefulness of the Dutch

\footnotetext{
${ }^{22}$ For example, a manager that exercises one stock option and subsequently sells the acquired share has three records on one day in the register reflecting the same disposition trade. First, the manager "sells" an option. Second, the manager buys a share at exercise price. Third, the manager sells the share at a price greater than the exercise price. This example illustrates the importance of carefully examining the records in the AFM register. A failure to do so would result in the purchase of the share at exercise price being treated as purchase, whereas in fact this transaction relates to a sale.

${ }^{23}$ Prior to October 2005, issuing companies were treated as corporate insiders under Wte 46b similar to officers, directors, and large shareholders. Hence, the register includes public disclosures of repurchase and share issue transactions by firms. Although these transactions are initiated by firms' management, they are not conducted for managers' personal accounts and hence are eliminated for the purpose of this study.
} 
insider trading sample for testing my predictions, I calculate event study abnormal returns around insider trading firm-days. Because smaller firms are likely to have greater information asymmetry (Lakonishok and Lee 2001), I also separately analyze abnormal returns around trades in "smaller" firms, i.e., excluding firms in the highest quintile of firm size (market capitalization).

\section{- Insert Figure 1 about here -}

Return patterns are presented in Figure 1 and Panels B and C of Table 2. Consistent with managers trading against prior price movements, share sales occur after price increases and purchases occur after price declines, on average. These patterns potentially reflect insiders' responses to market overreaction and mispricing (Rozeff and Zaman 1998). Alternatively, these patterns reflect changes in fundamentals and managers diversifying their portfolios. After the trade, purchases are associated with significantly positive abnormal returns. Share sales are associated with negative, but smaller and insignificant, future abnormal returns. This finding is consistent with Dutch insiders' share sales more likely being driven by liquidity and portfolio rebalancing needs. Focusing on the "smaller firm" sub-sample, results are similar for share sales, while abnormal returns accentuate for purchases. Overall, these return patterns are consistent with prior research and suggest the sample is useful for testing my predictions, in particular for insider share purchases. Examining purchases for smaller firms potentially increases the power of the tests due to the stronger abnormal return patterns.

\subsection{Main models}

H1 is tested using the following multivariate OLS regression model (firm and time subscripts omitted for brevity):

$$
V P=\alpha_{0}+\alpha_{1} B U Y+\alpha_{2} \text { SELL }+ \text { Controls }+ \text { TimeDummies }+\varepsilon
$$


where $V P$ captures the V/P ratio based on RIV, $B U Y$ is an indicator variable set equal to one if there is at least one insider purchase in the firm-month, zero otherwise, SELL is an indicator variable set equal to one if there is at least one insider sale in the firm-month, zero otherwise. Note that given $\mathrm{H} 1$, equation (7) is a reverse regression model which allows for an examination of the association between V/P ratios and insider purchasing and selling at the same time, while controlling for a range of correlated factors. I expect $\alpha_{1}\left(\alpha_{2}\right)$ to be positive (negative).

I also test the extent to which insider trading decisions are associated with V/P ratios versus other, previously examined, proxies for mispricing. For this purpose, I additionally estimate the following logit regression with either the $B U Y$ or SELL indicator as the dependent variable:

$$
B U Y / S E L L=\beta_{0}+\beta_{1} V P+\text { OtherProxies }+ \text { Controls }+ \text { TimeDummies }+\varepsilon
$$

where OtherProxies are the book-to-market ratio and prior returns. Results from this estimation allow for a better comparison with prior studies which are mainly focused on the mispricing drivers of insider trades (Rozeff and Zaman 1998; Jenter 2005; Piotroski and Roulstone 2005).

The following OLS regression model is used to test $\mathrm{H} 2$ :

$$
B H A R=\beta_{0}+\beta_{1} B U Y+\beta_{2} S E L L+\beta_{3} V P+\text { Controls }+ \text { TimeDummies }+\mathcal{E}
$$

where BHAR is the future abnormal (size-adjusted) buy-and-hold return. Following prior research which generally measures the abnormal returns after insider trades over periods of six months (e.g., Huddart and Ke 2007) or one year (e.g., Piotroski and Roulstone 2005), I create variables BHAR6m and BHARI2m that capture the six- and 12-month buy-and-hold abnormal returns after the month of interest, respectively.

Due to the panel structure of the data and the autocorrelation in monthly V/P ratios (e.g., Lee and Swaminathan 1999) and other control variables, I adjust standard errors in all pooled analyses for two-way clustering by firm and month (Petersen 2009; Gow et al. 2010). In addition, 
I control for time effects by including separate indicator variables for years and months. Lastly, all continuous variables are winsorized to the $1^{\text {st }}$ and $99^{\text {th }}$ percentiles of their distributions.

\subsection{Control variables}

Prior research suggests insider trading is more profitable in smaller firms (e.g., Seyhun 1986). At the same time, firm size affects stock returns (Fama and French 1992) and investors may have more difficulty in assessing the valuation implications of public information for smaller firms (e.g., Zhang 2006). Hence, I control for firm size (SIZE) using market capitalization. Because of its relation with returns (Fama and French 1992), insider trading (Lakonishok and Lee 2001; Piotroski and Roulstone 2005), and mechanical relation with V/P, I also control for book-tomarket $(B P)$.

Insiders are more likely to buy shares after price declines and sell after price increases. While this is partly captured by the inclusion of $B P$, I further control for recent price changes by including the 12-month buy-and-hold return for the period ending the previous month (BHRPRE). While VP captures mispricing, BHRPRE measures recent price changes that may reflect changes in firm fundamentals. Following Ali et al. (2003), I further control for leverage $(L E V)$, analyst following (NUMEST), analyst forecast dispersion (DISP), market beta (BETA), and idiosyncratic return volatility $(I D V O L)$. Controlling for idiosyncratic return volatility is potentially important in this setting, as Ben-David and Roulstone (2010) show that the profitability of insider trades is positively related to idiosyncratic risk. Following Brochet (2010), I further control for loss firms (LOSS) and R\&D intensive firms $(R N D)$.

Lastly, equation (9) includes a variable equal to the inverse of stock price (INVPR) to avoid spurious inferences induced by price deflation. Brown and Pfeiffer (2008) argue that the empirical regularity of a negative correlation between price levels and future returns may lead to 
misleading conclusions regarding mispricing of price-deflated variables. They show that controlling for this empirical regularity can have important effects on inferences drawn from regressions of future abnormal returns on price-deflated variables. Controlling for the deflator is important in this study given that $i$ ) price levels affect insiders' trading decisions (Rozeff and Zaman 1998; Heath et al. 1999) and ii) price deflation could induce an appearance of mispricing.

\section{Findings}

\subsection{Descriptive statistics}

Table 3 presents descriptive statistics on test and control variables. The average value-to-price ratio $(V P)$ is 1.11 , suggesting the average firm is slightly undervalued. However, this average critically depends on the discount rate and growth rate assumptions and the focus of this study is on cross-sectional variation in $\mathrm{V} / \mathrm{P}$ ratios. Insider trading is relatively infrequent, with $2.7 \%$ of firm-months having insider purchase activity and 5.9\% of firm-months having insider sales. The control variables and future return variables show substantial cross-sectional variation.

\section{- Insert Table 3 about here -}

Table 4 presents means for all variables for quintile portfolios sorted on V/P. As preliminary evidence for $\mathrm{H} 1$, insider buying $(B U Y)$ is more likely in high V/P firms while selling $(S E L L)$ is more likely in low V/P firms. The difference between high and low V/P for insider selling, however, is not significant. This suggests that, on average, managers trade on mispricing of public information only when purchasing shares. These results should be interpreted with care, given that most control variables also vary with V/P. For example, there is a large difference in firm size $(S I Z E)$ between high and low V/P firms. Prior research suggests that insiders are more likely to buy (sell) in firms with smaller (greater) market capitalization (e.g., Seyhun 1986).

- Insert Table 4 about here - 
Table 4 reveals no significant association of V/P with B/P between Q1 and Q5, even though $\mathrm{B} / \mathrm{P}$ is a component of $\mathrm{V} / \mathrm{P}$ (see section 3 ). This suggests that $\mathrm{B} / \mathrm{P}$ and $\mathrm{V} / \mathrm{P}$ likely capture different constructs, highlighting the role of incorporating additional (forward-looking) information in RIV. Untabulated tests suggest that the Pearson (Spearman) correlation between the two variables equals $-0.039(0.147) .{ }^{24}$ Similarly, the difference in prior returns between Q1 and Q5 is not statistically significant, suggesting V/P captures different dimensions than prior returns.

The pattern of leverage $(L E V)$ across V/P ratio portfolios further highlights the difference between the $B P$ and $V P$ variables. Prior research suggests that high $\mathrm{B} / \mathrm{P}$ (value) firms are financially distressed and have high leverage ratios (e.g., Piotroski 2000). Untabulated tests confirm a negative Pearson (Spearman) correlation of -0.088 (-0.143) between B/P and leverage. Table 4, however, shows a strong positive association between V/P ratios and leverage, consistent with Ali et al. (2003). The descriptives further reveal that V/P is negatively associated with analyst following, beta, idiosyncratic return volatility, loss incidence, and R\&D activity.

The bottom rows of Table 4 present the average future buy-and-hold abnormal returns for the V/P portfolios. Recall that low V/P indicates relative overvaluation, while high V/P indicates relative undervaluation. Hence, low V/P should be associated with relatively low future returns when prices correct for overvaluation, while high V/P should be associated with higher future returns when prices correct for undervaluation. Results are consistent with this conjecture. For example, twelve-month abnormal buy-and-hold returns are $8.7 \%$ higher in high $\mathrm{V} / \mathrm{P}$ firms compared to low V/P firms. These findings are in line with prior empirical evidence on the

\footnotetext{
${ }^{24}$ However, the relation between the two variables is positive when focusing on Q2 through Q5. Untabulated tests suggest that the Pearson (Spearman) correlation equals 0.350 (0.353) when observations in Q1 are excluded. Nevertheless, these correlations are modest and suggest the two variables capture different underlying constructs.
} 
application of RIV in the U.S. (Frankel and Lee 1998; Ali et al. 2003; Bradshaw 2004) or in an international context (Barniv et al. 2010). ${ }^{25}$

\subsection{Tests of the association between insider trading and V/P ratios}

Table 5 presents results of estimating equations (7) and (8). In these analyses, I use the monthly quintile ranks of firm size (SIZEQ) and book-to-market $(B P Q)$, while analyst following (NUMEST) and dispersion (DISP) are log-transformed. In estimating (8), I further use the monthly quintile rank of $\mathrm{V} / \mathrm{P}(V P Q)$. Consistent with $\mathrm{H} 1$, results of Model 1 suggest that insider buying $(B U Y)$ is significantly positively associated with V/P. V/P ratios are on average 0.146 higher in firm-months with insider buying (p-value: 0.004). Results for insider sales are weaker with V/P ratios being 0.055 lower in firm-months with insider selling (p-value: 0.086 ).

\section{- Insert Table 5 about here -}

Models 2 and 3 provide similar insights based on the estimation of equation (8). The propensity for an insider to buy shares in a given month is significantly greater when a firm is undervalued (high V/P). The untabulated marginal effect associated with the coefficient of 0.199 (p-value: 0.006) equals 0.00524 , which suggests that - after controlling for other determinants of the propensity to buy - the difference in propensity to buy shares is 2.1 percent higher in months with undervaluation compared to months with overvaluation. ${ }^{26}$ Given the average insider buying activity of 2.7 percent for the full sample, this suggests the effect of mispricing on the propensity for insiders to buy shares is economically significant. That is, the likelihood of insider buying

\footnotetext{
${ }^{25}$ Although the main interest of this study is in the six and twelve-month holding periods due to the focus on insider trades, I also examined the abnormal returns for 18- and 24-month holding periods (not tabulated). For the 18 month holding period, the abnormal return differential increases to $14.9 \%$, while it increases to $19.2 \%$ for the 24 -month holding period

${ }^{26}$ The $2.1 \%$ is calculated as follows. The marginal effect of 0.00524 (computed in STATA using the "margins" command) indicates the predicted change in $B U Y$ when $V P Q$ changes by one unit. Given that $V P Q$ takes on values between 1 and 5 , the marginal effect of switching from the smallest to the largest group is $4 * 0.00524=0.02095$ $(=2.1 \%)$.
} 
activity increases by 38.8 percent when a company moves from no mispricing (Q3) to undervaluation (Q5), holding all else constant. ${ }^{27}$

Consistent with the weaker result on insider sales in Model 1 and the insignificant abnormal returns in Table 2, Model 3 indicates that mispricing does not significantly affect the propensity for insiders to sell shares. Comparing the coefficients on $V P Q$ in Models 2 and 3 to the coefficients on $B P Q$ and $B H R P R E$, I find that the propensity to buy is not driven by either bookto-market or prior returns. On the other hand, the propensity to sell is driven by these factors in ways consistent with prior studies. This suggest that the previously documented association between insider sales and variables such as book-to-market and prior returns (Rozeff and Zaman 1998; Jenter 2005; Piotroski and Roulstone 2005) more likely reflects insiders responding to price changes that are supported by firm fundamentals rather than driven by mispricing. Insider buying, on the other hand, is more likely driven by price changes that signal undervaluation.

Models 4 through 6 present the same set of analyses for the sub-sample of smaller firms, which excludes observations of firms in the largest monthly size quintile. Results are qualitatively similar to the results for the full sample of observations. Specifically, mispricing does not appear to differentially affect the propensity to buy or sell shares in smaller firms.

Overall, Table 5 provides evidence consistent with H1 suggesting that managers more likely buy shares in their firm when it is undervalued. To a much lesser extent, managers sell shares of overvalued firms. The asymmetric association with V/P ratios is consistent with the result of larger absolute abnormal returns after insider purchases relative to insider sales. Whether the abnormal returns after insider trades reflect managers' private information or their ability to detect and trade on market misvaluations is examined in the following section. Results above suggest that mispricing is likely to explain at least a portion of these abnormal returns.

${ }^{27}(2 / 4 * 0.02095) / 0.027=0.388$. 


\subsection{Private information versus public information as explanation for abnormal returns}

Table 6 presents results of testing H2. In Models 1 and 3, equation (9) is estimated with six and twelve month horizon buy-and-hold abnormal returns as the dependent variable, respectively, without controlling for mispricing (V/P). Consistent with Figure 1 and Table 2, insider purchases $(B U Y)$ are associated with significantly positive future abnormal returns. Insider sales $(S E L L)$ are not significantly associated with future abnormal returns. A comparison of the coefficients on $B U Y$ in Models 1 and 3 suggests that Dutch insiders realize their abnormal returns mainly in the six months after the month of trade.

\section{- Insert Table 6 about here -}

Models 2 and 4 control for mispricing by including the quintile rank of the $\mathrm{V} / \mathrm{P}$ ratio $(V P Q)$. H2 predicts insider purchases are associated with positive future abnormal returns after controlling for undervaluation. Combined with the evidence on H1 suggesting purchases are associated with undervaluation, evidence supporting $\mathrm{H} 2$ is consistent with the abnormal returns after insider purchases being explained by both public and private information.

V/P ratios are significantly positively associated with future abnormal returns. The coefficient on $V P Q$ jumps from 0.014 to 0.024 when moving from the six-month to twelve-month horizon. This is consistent with RIV based V/P ratios identifying mispricing after controlling for the range of other factors included in the regressions (further validating the use of RIV to identify market mispricing). Nevertheless, controlling for this mispricing only has small consequences for the association between $B U Y$ and future abnormal returns. For the six-month (twelve-month) horizon, the coefficient on $B U Y$ remains significant and only slightly declines from $0.075(0.071)$ to $0.073(0.066)$ when including $V P Q$.

- Insert Table 7 about here - 
Consistent with Brown and Pfeiffer (2008), INVPRQ loads significantly. This highlights the importance of controlling for the effect of price levels on future returns. Table 7 presents results for the sub-sample of smaller firms. Results are qualitatively similar, with the exception that the coefficients on $B U Y$ are larger in all specifications. Interestingly, the coefficients on $V P Q$ in Table 7 are approximately equal to those in Table $6(0.014$ versus 0.014 and 0.026 versus 0.024 for the six- and twelve-month horizons, respectively). Combined with the finding in Table 5 that mispricing does not differentially affect the propensity to trade in smaller firms, this suggests that

the incremental abnormal returns after insider purchases in smaller firms are more likely due to managers' incremental private information rather than more opportunity to act on mispricing.

Overall, I conclude that abnormal returns after insider trades reflect both managers' private information as well as their response to mispricing of public information.

\section{Additional analyses}

\subsection{Firm-specific time series regressions}

This section presents an alternative estimation method. Instead of estimating cross-sectional regressions on the pooled sample of firm-month observations, I estimate firm-specific OLS regressions for the sample of firms that meet two additional criteria: $i$ ) there is insider trading activity in at least one month, and $i$ ) the firm has at least ten monthly observations of $V P$. These criteria reduce the sample to 7,050 $(5,419)$ firm-month observations for 75 (63) distinct firms (smaller firms). This analysis allows a firm to act as its own control and identifies the extent to which V/P ratios are different for a firm in months where insiders trade, and the extent to which future abnormal returns for a firm are higher in months where insiders trade.

- Insert Table 8 about here - 
Regression summary statistics are presented in Table 8 . Results suggest that V/P ratios are significantly higher in firm-months with insider purchases. The ratios of positive to negative coefficients of 42:21 and 35:16 in Models 1 and 2, respectively, further confirm the economic significance of this effect. ${ }^{28}$ Although negative, the average coefficients on sales are not significantly different from zero. Thus, these tests confirm the association between insiders' purchase decisions and undervaluation.

Models 3 and 4 re-examine the association between insider trading and future abnormal returns while controlling for V/P ratios. For brevity, results are presented for the twelve-month buy-and-hold abnormal returns (BHAR12m) only, while results using the six-month horizon are qualitatively similar. Consistent with the findings in Tables 6 and 7, I find a significantly positive association between $B U Y$ and $B H A R$. The coefficient is positive in about twice as many times as it is negative. In Model 3, the average coefficient on SELL is negative and only marginally significant. Combined with the coefficient on SELL in Model 4 and the results in Tables 6 and 7 , I conclude that insiders gain little from selling shares based on private information or mispricing. Results for insider purchases are, however, robust to this alternative method of estimation.

\subsection{AEG valuation}

To the extent that the empirical implementation of $\mathrm{V} / \mathrm{P}$ measures mispricing with error, it may insufficiently control for insiders trading on public rather private information in the future returns regressions. In this section, I evaluate the effect on my main results of using AEG as alternative to RIV valuation.

\footnotetext{
${ }^{28}$ Note that in model 1 the estimated coefficient on $B U Y$ is zero in 12 cases $(=75-42-21)$. This is because the sample is restricted to firms having any buying or selling over the sample period. Restricting the analyses to the 63 firms with insider buying or 64 firms with insider selling does not affect the presented results. The same applies to the results based on the sample of smaller firms.
} 
Practical implemention of AEG requires a finite forecast horizon. Following prior studies, I require forecasts of earnings per share in the next two periods:

$$
V_{0}(A E G)=\frac{e p s_{1}}{r_{e}}+\frac{a g r_{2}}{r_{e}\left(r_{e}-\Delta a g r\right)}
$$

where $\Delta a g r$ equals the average expected rate of growth in abnormal earnings growth beyond the forecast horizon. Easton (2004) finds that the average market implied rate of growth in abnormal earnings growth equals $2.9 \%$ for a sample of U.S. listed firms. Penman (2005) applies a perpetual growth rate of $4 \%$. Gode and Mohanram (2003) set $\Delta a g r$ equal to three percent below the tenyear U.S. treasury bill rate. In this study, I follow Penman (2005) and use a growth rate of four percent as in the RIV model. ${ }^{29}$ Because AEG requires positive EPS forecasts as inputs (Gode and Mohanram 2003; Jorgensen et al. 2011), the sample of firm-months is reduced to 8,697 observations $(6,926$ observations for smaller firms $)$.

\section{- Insert Table 9 about here -}

Table 9 presents results of using VP_AEG, the V/P ratio derived from equation (10). Panel A first presents firm characteristics for portfolios formed based on $V P \_A E G$. Consistent with Penman (2005), I find that value-to-price ratios based on AEG are substantially higher and more volatile than ratios based on RIV. For example, the average value of $V P \_A E G$ for the middle portfolio Q3 equals 2.070, suggesting extreme undervaluation. Similar to the statistics for the RIV based V/P ratios in Table 4, VP_AEG is negatively associated with firm size (SIZE) and analyst following (NUMEST). However, the associations with BP, BHRPRE, LEV, DISP, BETA, IDVOL, LOSS, and RND are inconsistent with the associations in Table 4. Hence, although I find a positive association between $V P \_A E G$ and $V P$, these ratios appear to capture quite distinct

\footnotetext{
${ }^{29}$ Again, as with the RIV implementation, the discount rate is set equal to ten percent for all firms. Results are unaffected by changing the constant discount rate and growth rate assumptions, or using firm-specific discount rates based on CAPM.
} 
elements of firms. ${ }^{30}$ Univariate results for insider trading are opposite to those based on RIV in Table 4. VP_AEG is associated with insider sales rather than purchases.

The bottom rows of Table 9, Panel A, suggest that sorts based on AEG do not result in predictable differences in future return across V/P portfolios. For example, the twelve month return differential between high and low $V P \_A E G$ observations is $0.6 \%$, statistically and economically insignificant. ${ }^{31}$ Thus, AEG valuation appears to be of limited practical use for the identification of mispricing. This descriptive analysis provides further validation for the use of RIV based V/P ratios as the main measure of mispricing. It also adds to Jorgenson et al. (2011) who find that RIV is more strongly associated with observed stock prices than AEG. ${ }^{32}$ Although this suggests that RIV is more useful for the detection of mispricing than AEG, I do further test the effect of using AEG as alternative valuation model.

Panel B of Table 9 presents results of multivariate analyses of the association between insider trading and V/P based on the both models. I find no significant association between insider trades and VP_AEG, with the exception of a marginally significant coefficient on sales (p-value: 0.089 ) for smaller firms in model 3. Results for valuations based on RIV for the reduced sample of $V P \_A E G$ observations are, however, consistent with those presented in Table 5. Panel C of Table 9 presents results of estimating equation (9) with $V P \_A E G Q$. Results suggest $V P \_A E G Q$ is not significantly associated with future returns. After controlling for $V P \_A E G Q$, I find that $B U Y$ and RIV based $V P Q$ are still significantly positively associated with future returns.

\footnotetext{
${ }^{30}$ Untabulated analysis reveals that the (Spearman rank) correlation between $V P$ and $V P \_A E G$ for the sample of 8,199 firm-months equals 0.37 (0.31).

${ }^{31}$ Untabulated tests suggest that increasing the holding period to 18 or 24 months provides similar insights. The return differentials (Q5-Q1) equal $1.2 \%$ and $0.3 \%$ for the 18 and 24 month holding periods, respectively.

${ }^{32}$ Jorgenson et al. (2011) find that AEG valuations implemented using longer forecast horizons improve the model's ability to explain observed stock prices, but still RIV estimations using similar forecast horizons outperform AEG estimations. In untabulated tests, I find that increasing the forecast horizon for AEG to three or five years does not improve the model's ability to detect mispriced securities.
} 


\section{Summary and conclusions}

This study examines the association between fundamental valuations and insider share trades to provide evidence on the extent to which abnormal returns after insider trades can be explained by public versus private information. The study is motivated by evidence in the corporate finance literature which suggests managers recognize and act on situations where market prices deviate from fundamental values. At the same time, an extensive literature documents that personal share trades by managers are associated with future abnormal returns. To the extent that managers also respond to mispricing of public information when trading on their personal accounts, abnormal returns after insider trades are potentially explained by reversals of prior mispricing.

I find that Dutch managers' share purchase decisions are associated with undervaluation as indicated by value-to-price ratios based on the Residual Income Valuation model. While such undervaluation results in predictable (positive) price reversals, I further find that positive abnormal returns after insider purchases persist after orthogonalizing insider purchases and future returns with respect to fundamental valuations. This suggests that the abnormal returns after insider purchases reflect private information as well as managers' responses to the mispricing of public information.

One important caveat of this study relates to the ability of empirical RIV estimates to identify mispricing. To the extent that RIV empirically measures fundamental value with noise, value-toprice ratios may insufficiently control for the effect of mispricing on future returns. Nevertheless, I find robust evidence suggesting that fundamental value-to-price ratios are associated with insider purchase decisions as well as future abnormal returns. On a related note, it is impossible to fully capture the motivations behind managers' trading decisions and researchers can only approximate these motivations from realized future returns. Instead of attempting to capture 
private information using noisy proxies for future news, this study takes a different approach and identifies the portion of abnormal returns that is not explained by public information.

I conclude that managers' insider trading decisions are at least partly motivated by temporary deviations between market prices and fundamentals. Although such trading contributes to the abnormal returns following insider trades, managers' purchases are associated with abnormal returns even after controlling for mispricing. This suggests that market participants and future research focused on disclosures of insider trades should take into consideration the possibility that such disclosures may signal (mispricing of) public information in addition to signaling private information about a company's prospects. Future research could also examine the extent to which the precision of financial reporting affects managers' public versus private information advantage. In a cross-country study, one could examine how differences in insider trading rules and enforcement affect managers' trading on public versus private information. Furthermore, future studies focused on corporate market transactions (e.g., share repurchases) may benefit from using fundamental valuation ratios in a similar fashion to assess the extent to which market timing is driven by mispricing versus private information. 


\section{References}

Aboody, D., and Lev, B. (2000) Information Asymmetry, R\&D, and Insider Gains, The Journal of Finance, 55(6), pp. 2747-2766.

AFM (2010) Insider Dealing, http://nl.sitestat.com/afm/afm/s?afm.en.pdf.insiderdealing\&ns_type=pdf\&ns_url=http://www.afm.nl/layouts/afm/default.aspx /media/files/brochures/2010/engmarket-manipulation/insider-dealing.ashx.

Ali, A., Hwang, L.-S. and Trombley, M.A. (2003) Residual-Income-Based Valuation Predicts Future Stock Returns: Evidence on Mispricing vs. Risk Explanations, The Accounting Review, 78(2), pp. 377.

Ali, A., Wei, K.D. and Zhou, Y. (2011) Insider Trading and Option Grant Timing in Response to Fire Sales (and Purchases) of Stocks by Mutual Funds, Journal of Accounting Research, 49(3), pp. 595-632.

Badertscher, B., Hribar, P. and Jenkins, N.T. (2011) Informed Trading and the Market Reaction to Accounting Restatements, The Accounting Review, 86(5), pp. 1519-1547.

Baker, M. and Wurgler, J. (2002) Market Timing and Capital Structure, The Journal of Finance, 57(1), pp. 1-32.

Barniv, R., Hope, O.-K., Myring, M. and Thomas, W.B. (2010) International Evidence on Analyst Stock Recommendations, Valuations, and Returns, Contemporary Accounting Research, 27(4), pp. 1131-1167.

Bartov, E. and Mohanram, P. (2004) Private Information, Earnings Manipulations, and Executive Stock-Option Exercises, The Accounting Review, 79(4), pp. 889-920.

Beaver, W.H. and Ryan, S.G. (2005) Conditional and Unconditional Conservatism: Concepts and Modeling, Review of Accounting Studies, 10(2), pp. 269-309.

Ben-David, I. and Roulstone, D.T. (2010) Idiosyncratic Risk and Corporate Transactions, Working paper, Ohio State University.

Bernard, V.L. and Thomas, J.K. (1989) Post-Earnings-Announcement Drift: Delayed Price Response or Risk Premium? Journal of Accounting Research, 27, pp. 1-36.

Bettis, C., Coles, J. and Lemmon, M.L. (2000) Corporate Policies Restricting Trading by Insiders, Journal of Financial Economics, 57, pp. 191-220.

Betzer, A. and Theissen, E. (2009) Insider Trading and Corporate Governance: The Case of Germany, European Financial Management, 15(2), pp. 402-429.

Bhattacharya, U. and Daouk, H. (2002) The World Price of Insider Trading, The Journal of Finance, 57(1), pp. 75108.

Bradshaw, M.T. (2004) How Do Analysts Use Their Earnings Forecasts in Generating Stock Recommendations?, The Accounting Review, 79(1), pp. 25-50.

Brav, A., Graham, J.R., Harvey, C.R. and Michaely, R. (2005) Payout Policy in the 21st Century, Journal of Financial Economics, 77(3), pp. 483-527.

Brief, R.P. (2007) Accounting Valuation Models: A Short Primer, Abacus, 43(4), pp. 429-437.

Brochet, F. (2010) Information Content of Insider Trades before and after the Sarbanes-Oxley Act, The Accounting Review, 85(2), pp. 419.

Brown, J. and Pfeiffer, J. (2008) Do Investors Under-React to Information in Analysts' Earnings Forecasts? Journal of Business Finance \& Accounting, 35(7-8), pp. 889-911.

Cheng, Q. and Lo, K. (2006) Insider Trading and Voluntary Disclosures, Journal of Accounting Research, 44(5), pp. 815-848.

Christensen, H.B., Hail, L. and Leuz, C. (2011) Capital-Market Effects of Securities Regulation: Hysteresis, Implementation, and Enforcement, Working paper, University of Chicago and University of Pennsylvania. 
Core, J.E., Guay, W., Richardson, S. and Verdi, R. (2006) Stock Market Anomalies: What Can We Learn from Repurchases and Insider Trading? Review of Accounting Studies, 11(1), pp. 49-70.

Cziraki, P., De Goeij, P. and Renneboog, L. (2011) Corporate Governance Rules and Insider Trading Profits, Working paper, Tilburg University.

Dardas, K. and Güttler, A. (2011) Are Directors' Dealings Informative? Evidence from European Stock Markets, Financial Markets and Portfolio Management, 25(2), pp. 111-148.

Degryse, H., De Jong, F. and Lefebvre, J. (2009) An Empirical Analysis of Legal Insider Trading in the Netherlands, Working paper, Tilburg University.

Dong, M., Hirshleifer, D., Richardson, S. and Teoh, S.H. (2006) Does Investor Misvaluation Drive the Takeover Market? The Journal of Finance, 61(2), pp. 725-762.

Easton, P.D. (2004) PE Ratios, PEG Ratios, and Estimating the Implied Expected Rate of Return on Equity Capital, The Accounting Review, 79(1), pp. 73-95.

Edwards, E.O. and Bell, P.W. (1961) The Theory and Measurement of Business Income, University of California Press, Berkeley.

Fama, E.F. and French, K.R. (1992) The Cross-Section of Expected Stock Returns, The Journal of Finance, 47(2), pp. 427-465.

Fidrmuc, J.P., Goergen, M. and Renneboog, L. (2006) Insider Trading, News Releases, and Ownership Concentration, The Journal of Finance, 61(6), pp. 2931-2973.

Fidrmuc, J.P., Korczak, A. and Korczak, P. (2011) Why are Abnormal Returns After Insider Transactions Larger in Better Investor Protection Countries? Working paper, Warwick Business School and University of Bristol.

Fishman, M.J. and Hagerty, K.M. (1990) The Optimal Amount of Discretion to Allow in Disclosure, The Quarterly Journal of Economics, 105(2), pp. 427-444.

Francis, J., Olsson, P. and Oswald, D.R. (2000) Comparing the Accuracy and Explainability of Dividend, Free Cash Flow, and Abnormal Earnings Equity Value Estimates, Journal of Accounting Research, 38(1), pp. 45-70.

Frankel, R. and Lee, C.M.C. (1998) Accounting Valuation, Market Expectation, and Cross-Sectional Stock Returns, Journal of Accounting and Economics, 25(3), pp. 283-319.

Frankel, R., and Li, X. (2004) Characteristics of a Firm's Information Environment and the Information Asymmetry Between Insiders and Outsiders, Journal of Accounting and Economics, 37(2), pp. 229-259.

Friederich, S., Gregory, A., Matatko, J. and Tonks, I. (2002) Short-run Returns around the Trades of Corporate Insiders on the London Stock Exchange, European Financial Management, 8(1), pp. 7-30.

Gode, D. and Mohanram, P. (2003) Inferring the Cost of Capital Using the Ohlson-Juettner Model, Review of Accounting Studies, 8(4), pp. 399-431.

Gow, I.D., Ormazabal, G. and Taylor, D.J. (2010) Correcting for Cross-Sectional and Time-Series Dependence in Accounting Research, The Accounting Review, 85(2), pp. 483.

Graham, J.R. and Harvey, C.R. (2001) The Theory and Practice of Corporate Finance: Evidence from the Field, Journal of Financial Economics, 60(2-3), pp. 187-243.

Grullon, G. and Ikenberry, D.L. (2000) What Do We Know About Stock Repurchases? Journal of Applied Corporate Finance, 13(1), pp. 31-51.

Heath, C., Huddart, S.J. and Lang, M. (1999) Psychological Factors and Stock Option Exercise., Quarterly Journal of Economics, 114(2), pp. 601-627.

Huddart, S.J. and Ke, B. (2007) Information Asymmetry and Cross-sectional Variation in Insider Trading, Contemporary Accounting Research, 24(1), pp. 195-232.

Huddart, S.J., Ke, B. and Shi, C. (2007) Jeopardy, Non-Public Information, and Insider Trading Around Sec 10-K and 10-Q Filings, Journal of Accounting and Economics, 43(1), pp. 3-36. 
Isidro, H., O'Hanlon, J. and Young S. (2006) Dirty Surplus Accounting Flows and Valuation Errors, Abacus, 42(3/4), pp. 302-344.

Jagolinzer, A.D., Larcker, D.F. and Taylor, D.J. (2011) Corporate Governance and the Information Content of Insider Trades, Journal of Accounting Research, 49(5), pp. 1249-1274.

Jeng, L.A., Metrick, A. and Zeckhauser, R. (2003) Estimating the Returns to Insider Trading: A PerformanceEvaluation Perspective, Review of Economics and Statistics, 85(2), pp. 453-471.

Jenter, D. (2005) Market Timing and Managerial Portfolio Decisions, The Journal of Finance, 60(4), pp. 1903-1949.

Jiang, X. and Lee B.S. (2005) An Empirical Test of the Accounting-Based Residual Income Model and the Traditional Dividend Discount Model, Journal of Business 78(4): 1465-1504.

Jorgensen, B.N., Lee, Y.G. and Yoo, Y.K. (2011) The Valuation Accuracy of Equity Value Estimates Inferred from Conventional Empirical Implementations of the Abnormal Earnings Growth Model: US Evidence, Journal of Business Finance \& Accounting, 38(3-4), pp. 446-471.

Kabir, R. and Vermaelen, T. (1996) Insider Trading Restrictions and the Stock Market: Evidence from the Amsterdam Stock Exchange, European Economic Review, 40(8), pp. 1591-1603.

Kallunki, J.-P., Nilsson, H. and Hellström, J. (2009) Why do insiders trade? Evidence based on unique data on Swedish insiders, Journal of Accounting and Economics, 48(1), pp. 37-53.

Ke, B., Huddart, S.J. and Petroni, K. (2003) What Insiders Know About Future Earnings and How They Use It: Evidence from Insider Trades, Journal of Accounting and Economics, 35(3), pp. 315-346.

Kolasinski, A. and Li, X. (2010) Are Corporate Managers Savvy About Their Stock Price? Evidence from Insider Trading After Earnings Announcements, Journal of Accounting and Public Policy, 29(1), pp. 27-44.

Lakonishok, J. and Lee, I. (2001) Are Insider Trades Informative? Review of Financial Studies, 14(1), pp. 79-11.

La Porta, R., Lopez-de-Silanes, F., Shleifer, A. and Vishny, R. (1998) Law and finance, Journal of Political Economy, 106, pp. 1113-1155.

Lee, C.M.C., Myers, J. and Swaminathan, B. (1999) What is the Intrinsic Value of the Dow? The Journal of Finance, 54(5), pp. 1693-1741.

Lee, C.M.C. and Swaminathan, B. (1999) Valuing the Dow: A Bottom-Up Approach, Financial Analysts Journal, 55(5), pp. 4.

Lundholm, R. and O'Keefe T. (2001) Reconciling Value Estimates from the Discounted Cash Flow Model and the Residual Income Model, Contemporary Accounting Research, 18(2), pp. 311-335.

Manne, H.G. (1966) Insider Trading and the Stock Market, New York: Free Press.

Ofek, E. and Yermack, D. (2000) Taking Stock: Equity-Based Compensation and the Evolution of Managerial Ownership, The Journal of Finance, 55(3), pp. 1367-1384.

Ohlson, J.A. (1995) Earnings, Book Values, and Dividends in Security Valuation, Contemporary Accounting Research, 11, pp. 661-687.

Ohlson, J.A. (2005) On Accounting-Based Valuation Formulae, Review of Accounting Studies, 10(2), pp. 323-347.

Ohlson, J.A. and Juettner-Nauroth, B.E. (2005) Expected EPS and EPS Growth as Determinantsof Value, Review of Accounting Studies, 10(2), pp. 349-365.

Palepu, K.G., Healy, P.M., Bernard, V.L. and Peek, E. (2007) Business Analysis and Valuation: IFRS Edition - Text and Cases: Using Financial Statements: 1st ed., Thomson Learning.

Peasnell, K. (1982) Some Formal Connections between Economic Values and Yields and Accounting Numbers, Journal of Business Finance \& Accounting, 9, pp. 361-381.

Penman, S. and Sougiannis, T. (1998) A Comparison of Dividend, Cash Flow, and Earnings Approaches to Equity Valuation, Contemporary Accounting Research, 15(3), pp. 343-383. 
Penman, S.H. (2001) On Comparing Cash Flow and Accrual Accounting Models for Use in Equity Valuation: A Response to Lundholm and O'Keefe, Contemporary Accounting Research, 18(4), pp. 681-692.

Penman, S.H. (2005) Discussion of "On Accounting-Based Valuation Formulae" and "Expected EPS and EPS Growth as Determinants of Value," Review of Accounting Studies, 10(2), pp. 367-378.

Petersen, M.A. (2009) Estimating Standard Errors in Finance Panel Data Sets: Comparing Approaches, Review of Financial Studies, 22(1), pp. 435-480.

Piotroski, J.D. (2000) Value Investing: The Use of Historical Financial Statement Information to Separate Winners from Losers, Journal of Accounting Research, 38, pp. 1-41.

Piotroski, J.D. and Roulstone, D.T. (2005) Do Insider Trades Reflect Both Contrarian Beliefs and Superior Knowledge About Future Cash Flow Realizations? Journal of Accounting and Economics, 39(1), pp. 55-81.

Pope, P.F., Morris, R.C. and Peel, D.A. (1990) Insider Trading: Some Evidence on Market Efficiency and Directors' Share Dealings in Great Britain, Journal of Business Finance \& Accounting, 17(3), pp. 359-380.

Roychowdhury, S. and Watts, R.L. (2007) Asymmetric Timeliness of Earnings, Market-to-Book and Conservatism in Financial Reporting, Journal of Accounting and Economics, 44(1-2), pp. 2-31.

Rozeff, M.S. and Zaman, M.A. (1998) Overreaction and Insider Trading: Evidence from Growth and Value Portfolios, The Journal of Finance, 53(2), pp. 701-716.

Seyhun, H.N. (1990) Do Bidder Managers Knowingly Pay Too Much for Target Firms? The Journal of Business, 63(4), pp. 439-464.

Seyhun, H.N. (1986) Insiders' Profits, Costs of Trading, and Market Efficiency, Journal of Financial Economics, 16(2), pp. 189-212.

Seyhun, H.N. (1998) Investment Intelligence from Insider Trading, The MIT Press.

Seyhun, H.N. and Bradley, M. (1997) Corporate Bankruptcy and Insider Trading, The Journal of Business, 70(2), pp. 189-216.

Sivakumar, K. and Waymire, G. (1994) Insider Trading Following Material News Events: Evidence from Earnings, Financial Management, 23(1), pp. 23-32.

Skaife, H.A., Veenman, D. and Wangerin, D.D. (2011). Internal Control over Financial Reporting and Managerial Rent Extraction: Evidence from the Profitability of Insider Trading, Working paper University of Wisconsin, Erasmus University, and Michigan State University.

Skinner, D. and Sloan, R. (2002) Earnings Surprises, Growth Expectations, and Stock Returns or Don't Let an Earnings Torpedo Sink Your Portfolio, Review of Accounting Studies, 7(2), pp. 289-312.

Sougiannis, T. and Yaekura, T. (2001) The Accuracy and Bias of Equity Values Inferred from Analysts' Earnings Forecasts., Journal of Accounting, Auditing \& Finance, 16(4), pp. 331-362.

Veenman, D. (2012) Disclosures of Insider Purchases and the Valuation Implications of Past Earnings Signals, The Accounting Review, 87(1), pp. 313-342.

Welch, J., Pannier, M., Barrachino, E., Bernd, J. and Ledeboer, P. (2005) Comparative Implementation of EU Directives (I) - Insider Dealing and Market Abuse, British Institute of International Law and Comparative Law.

Zhang, X.F. (2006) Information Uncertainty and Stock Returns, The Journal of Finance, 61(1), pp. 105-137.

Zingg, A., Lang, S. and Wyttenbach, D. (2007) Insider Trading in the Swiss Stock Market, Schweizerische Zeitschrift für Volkswirtschaft und Statistik, 143(3), pp. 331-362. 


\section{Figure 1}

\section{Cumulative average abnormal returns (CARs) around insider transactions}

\section{Panel A: All firms}

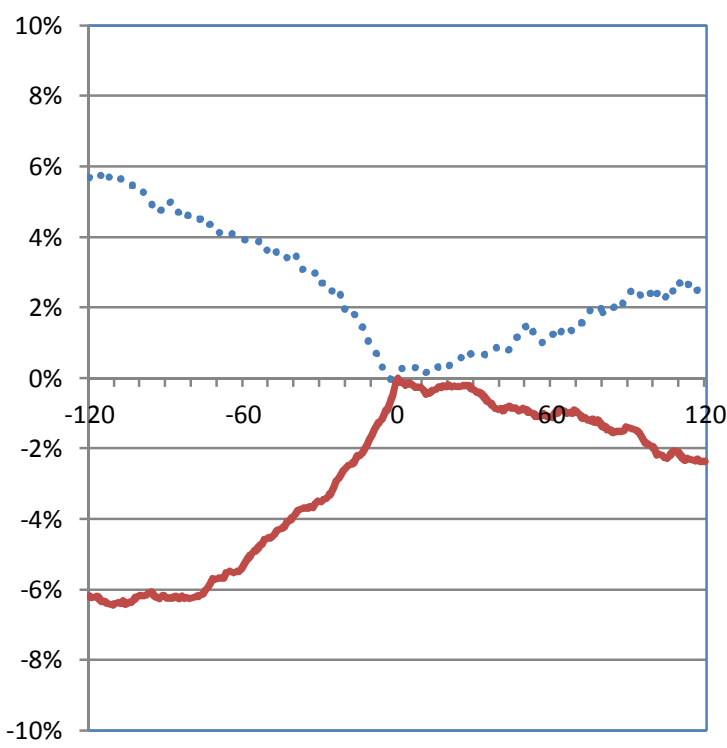

Panel B: Smaller firms

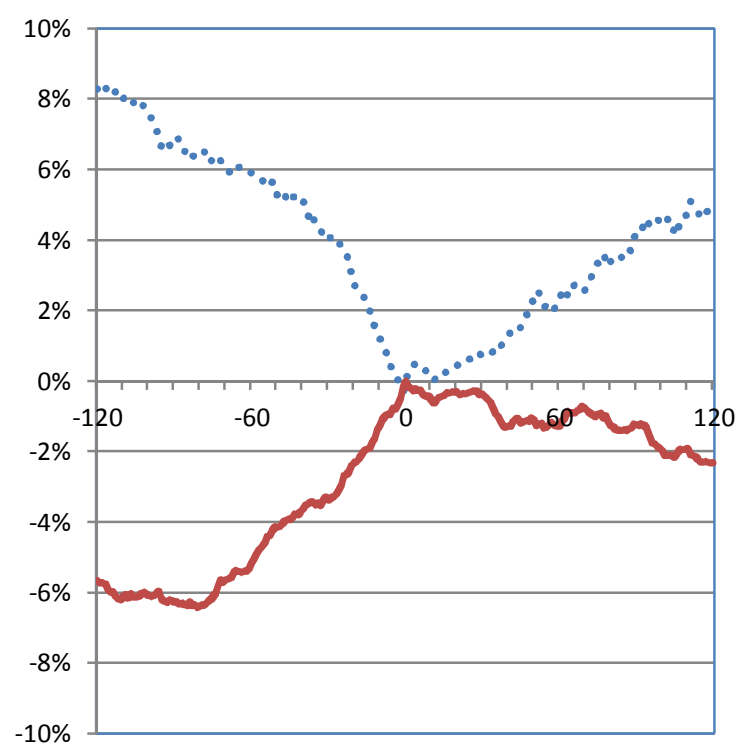

The horizontal axis reflects the number of business days relative to an insider trading event (firm-day). The dotted (solid) line reflects cumulative average abnormal returns (CARs) around insider purchase (sales) events. Panel A presents CARs around 708 insider purchase events and 1,477 insider sales events during the period 1999-2008 for firms listed on the Amsterdam Stock Exchange (see Table 2 for sample selection details). Abnormal returns are daily size-adjusted returns computed by subtracting the average daily return of similar-sized firms from an individual firm's return. Quintile portfolios are created at the beginning of each calendar month based on total market capitalization. Panel B presents CARs around 458 insider purchase events and 938 insider sales events for the sample of observations excluding the largest firms (i.e., excluding firms in quintile 5). 
Table 1

Sample selection

$\mathrm{n}$

Firms

Months of firms listed on the Amsterdam Stock Exchange in the intersection of COMPUSTAT Global and I/B/E/S

14,397

Less:

- Observations with missing one- or two-year ahead consensus earnings forecast on $\mathrm{I} / \mathrm{B} / \mathrm{E} / \mathrm{S}$

- Observations with missing three-year ahead consensus earnings forecast on $\mathrm{I} / \mathrm{B} / \mathrm{E} / \mathrm{S}$ and missing long-term growth forecast

- Observations without book value of equity available on COMPUSTAT for the most recent fiscal year

- Observations with negative book value of equity

- Observations with missing price data on $\mathrm{I} / \mathrm{B} / \mathrm{E} / \mathrm{S}$

- Observations with stock price below $€ 1$

- Observations with missing data on control variables

- Observations without 12-month future buy-and-hold returns

The initial sample of 14,397 firm-months is obtained by first identifying all firms in COMPUSTAT's "G_SECURITY" dataset on WRDS that have their equity traded on the Amsterdam Stock Exchange $(\mathrm{EXCHG}=104)$ and for which the I/B/E/S ticker is provided (IBTIC). Next, only those firms incorporated in the Netherlands are retained (COMPUSTAT's country incorporation code FIC). For the remaining list of firms, analyst forecast data is obtained from the I/B/E/S summary file. This procedure resulted in a sample of 14,397 firm-months for 210 distinct firms. Earnings forecasts from I/B/E/S are the monthly median consensus EPS forecast for the forthcoming (FPI=1) and subsequent $(\mathrm{FPI}=2)$ fiscal year. Monthly $\mathrm{I} / \mathrm{B} / \mathrm{E} / \mathrm{S}$ forecasts are matched with COMPUSTAT firm-years based on the most recently announced fiscal year in the forecast month (variable FY0EDATS in I/B/E/S is matched with variable DATADATE in COMPUSTAT). 
Table 2

Insider trading data: Sample selection and abnormal returns

Panel A: Data filtering

$\mathrm{n}$

Firms

Initial sample of transaction-records collected from AFM for the period April 1999

through December 2008

18,364

231

Less:

- Firms not on Compustat Global

$\begin{array}{ll}-583 & -42\end{array}$

- Foreign firms listed on Amsterdam Stock Exchange

$-1,733 \quad-25$

- Repurchases, equity issues, and private transactions

$-5,867 \quad-15$

- Transactions in irregular instruments

$-1,672$

$-7$

- Option grants and other transactions in stock options

Final sample of transaction-records

$-1,367$

$-5$

7,142 137

Panel B: Abnormal returns around insider trades

\begin{tabular}{lcccccc}
\hline & \multicolumn{2}{c}{ Purchases $(\mathrm{n}=708)$} & & \multicolumn{2}{c}{ Sales $(\mathrm{n}=1,477)$} \\
\cline { 2 - 3 } \cline { 5 - 6 } & \multicolumn{1}{c}{ CAR } & t-stat & & & CAR & t-stat \\
\hline$[-120,0)$ & $-6.01 \%$ & $2.68 * * *$ & & $6.01 \%$ & $4.66 * * *$ \\
{$[-10,0)$} & $-1.28 \%$ & $-2.51 * *$ & & $1.56 \%$ & $4.82 * * *$ \\
{$[0,0]$} & $0.28 \%$ & $2.50 * *$ & & $0.16 \%$ & $2.01 * *$ \\
{$[0,10]$} & $0.62 \%$ & $2.67 * * *$ & & $-0.11 \%$ & -0.48 \\
{$[0,120]$} & $2.93 \%$ & $2.06 * *$ & & $-2.20 \%$ & -1.48 \\
\hline
\end{tabular}

Panel C: Abnormal returns around insider trades - smaller firms

\begin{tabular}{|c|c|c|c|c|}
\hline & \multicolumn{2}{|c|}{ Purchases $(n=458)$} & \multicolumn{2}{|c|}{ Sales $(n=938)$} \\
\hline & CAR & t-stat & CAR & t-stat \\
\hline$[-120,0)$ & $-8.68 \%$ & $-2.72 * * *$ & $5.50 \%$ & $3.06 * * *$ \\
\hline$[-10,0)$ & $-1.69 \%$ & $-2.73 * * *$ & $1.21 \%$ & $2.64 * * *$ \\
\hline$[0,0]$ & $0.31 \%$ & $2.25 * *$ & $0.17 \%$ & 1.64 \\
\hline$[0,10]$ & $0.60 \%$ & $2.17 * *$ & $-0.26 \%$ & -0.78 \\
\hline$[0,120]$ & $5.23 \%$ & $2.76 * * *$ & $-2.15 \%$ & -1.24 \\
\hline
\end{tabular}

Insider transactions for firms registered in The Netherlands are collected from the public register of the Autoriteit Financiële Markten (AFM). Panel A presents the data filtering procedure for transaction records identified in the AFM register. One transaction by an insider is often reflected in multiple records. Panel B presents abnormal returns for windows around insider trading days. Multiple transactions are aggregated by firm-day and duplicate firm-days are eliminated. Abnormal returns are daily size-adjusted returns computed by subtracting the average return of similar-sized firms from an individual firm's return (returns are cum-dividend price relatives computed from COMPUSTAT Security Daily data). Quintile portfolios are created at the beginning of each calendar month based on market value. Panel $\mathrm{C}$ presents results for the sample of observations excluding the largest firms (i.e., excluding firms in size quintile 5). In Panels B and C, t-statistics are based on robust standard errors adjusted for two-way clustering by firm and calendar month (Petersen 2009). ***,**, and ** denote significance at the 0.01, 0.05, and 0.10 level respectively. 
Table 3

Descriptive statistics on test and control variables

\begin{tabular}{|c|c|c|c|c|c|c|}
\hline & $\mathrm{n}$ & Mean & St. dev. & $\mathrm{Q} 1$ & Median & Q3 \\
\hline \multicolumn{7}{|c|}{ Mispricing variable } \\
\hline$V P$ & 9,441 & 1.110 & 0.774 & 0.774 & 1.056 & 1.462 \\
\hline \multicolumn{7}{|c|}{ Insider trading variables } \\
\hline$B U Y$ & 9,441 & 0.027 & 0.163 & 0 & 0 & 0 \\
\hline SELL & 9,441 & 0.059 & 0.236 & 0 & 0 & 0 \\
\hline \multicolumn{7}{|c|}{$\underline{\text { Control variables }}$} \\
\hline SIZE & 9,441 & 2,965 & 7,305 & 143 & 458 & 1,408 \\
\hline$B P$ & 9,441 & 0.723 & 0.728 & 0.284 & 0.490 & 0.857 \\
\hline BHRPRE & 9,441 & 0.094 & 0.476 & -0.213 & 0.043 & 0.326 \\
\hline$L E V$ & 9,441 & 0.606 & 0.179 & 0.516 & 0.637 & 0.729 \\
\hline NUMEST & 9,441 & 11.841 & 9.287 & 5 & 9 & 16 \\
\hline DISP & 9,441 & 0.198 & 0.297 & 0.050 & 0.110 & 0.210 \\
\hline BETA & 9,441 & 1.075 & 0.656 & 0.625 & 0.922 & 1.379 \\
\hline$I D V O L$ & 9,441 & 0.096 & 0.043 & 0.068 & 0.083 & 0.114 \\
\hline LOSS & 9,441 & 0.129 & 0.336 & 0 & 0 & 0 \\
\hline$R N D$ & 9,441 & 0.204 & 0.403 & 0 & 0 & 0 \\
\hline \multicolumn{7}{|c|}{ Future return variables } \\
\hline BHAR6m & 9,441 & 0.000 & 0.242 & -0.136 & -0.004 & 0.129 \\
\hline BHAR $12 \mathrm{~m}$ & 9,441 & 0.000 & 0.348 & -0.205 & -0.009 & 0.187 \\
\hline
\end{tabular}

$V P$ is the value-to-price ratio, where value is calculated using the RIV model and price is obtained from I/B/E/S. $B U Y(S E L L)$ is an indicator variable equal to one if a firm-month is identified as having insider purchases (sales), and zero otherwise. SIZE equals the market value of equity at the beginning of the month based on $\mathrm{I} / \mathrm{B} / \mathrm{E} / \mathrm{S}$ share price and number of shares outstanding; $B P$ equals the book-to-market ratio computed as book value per share (Compustat data item CEQ divided by number of shares from I/B/E/S) scaled by $\mathrm{I} / \mathrm{B} / \mathrm{E} / \mathrm{S}$ share price; BHRPRE is the buy-andhold return over the prior 12-month period; LEV is the ratio of total liabilities (LT) to total assets (AT); NUMEST equals the number of estimates contributing to the consensus forecast of forthcoming earnings per share from $\mathrm{I} / \mathrm{B} / \mathrm{E} / \mathrm{S} ; D I S P$ is the standard deviation of earnings per share estimates from $\mathrm{I} / \mathrm{B} / \mathrm{E} / \mathrm{S}$, set equal to zero if NUMEST $=1$; BETA is the CAPM beta estimated using OLS regressions of monthly stock returns on the equally weighted market portfolio for the past 60 months (requiring a minimum of 18 monthly returns); IDVOL is the standard deviation of the CAPM regression residuals; LOSS (RND) is an indicator variable equal to one if the firm reported a loss (R\&D expenditure) in the most recent fiscal year, zero otherwise. BHAR6m (BHAR12m) is the buyand-hold size-adjusted return over the six (twelve) month period starting the following month. In multivariate analyses, the independent variables SIZE, $B P$, and $V P$ are transformed to their monthly quintile ranks (SIZEQ, $B P Q$, and $V P Q$, respectively). 
Table 4

Insider activity, firm characteristics, and future returns partitioned by the magnitude of V/P

\begin{tabular}{|c|c|c|c|c|c|c|c|}
\hline & Q1 & $\mathrm{Q} 2$ & Q3 & Q4 & Q5 & Q5-Q1 & t-stat \\
\hline$\overline{V P}$ & 0.173 & 0.864 & 1.138 & 1.416 & 2.001 & 1.828 & $17.70 * * *$ \\
\hline$B U Y$ & 0.019 & 0.024 & 0.024 & 0.031 & 0.040 & 0.021 & $2.37 * *$ \\
\hline SELL & 0.050 & 0.085 & 0.077 & 0.050 & 0.035 & -0.015 & -1.00 \\
\hline SIZE & 5,410 & 5,419 & 2,288 & 1,137 & 463 & -4947.63 & $-3.25 * * *$ \\
\hline$B P$ & 0.971 & 0.559 & 0.578 & 0.656 & 0.856 & -0.115 & -1.10 \\
\hline BHRPRE & 0.081 & 0.130 & 0.103 & 0.110 & 0.045 & -0.036 & -0.79 \\
\hline$L E V$ & 0.517 & 0.586 & 0.616 & 0.639 & 0.674 & 0.156 & $4.87 * * *$ \\
\hline NUMEST & 13.527 & 15.568 & 11.876 & 9.915 & 8.163 & -5.364 & $-3.82 * * *$ \\
\hline DISP & 0.260 & 0.167 & 0.145 & 0.161 & 0.259 & -0.001 & -0.02 \\
\hline BETA & 1.292 & 1.052 & 1.011 & 0.977 & 1.039 & -0.253 & $-2.29 * *$ \\
\hline$I D V O L$ & 0.114 & 0.096 & 0.091 & 0.087 & 0.090 & -0.025 & $-3.42 * * *$ \\
\hline LOSS & 0.325 & 0.093 & 0.060 & 0.062 & 0.105 & -0.219 & $-3.83 * * *$ \\
\hline$R N D$ & 0.323 & 0.245 & 0.201 & 0.135 & 0.112 & -0.211 & $-2.87 * * *$ \\
\hline BHAR6m & -0.031 & -0.012 & 0.002 & 0.028 & 0.013 & 0.044 & $2.10 * *$ \\
\hline BHAR $12 m$ & -0.056 & -0.015 & -0.003 & 0.044 & 0.032 & 0.087 & $2.47 * *$ \\
\hline
\end{tabular}

Observations are sorted into quintile portfolios based on the magnitude of $V P$ in every calendar month. All variables are defined as in the notes to Table 3. t-statistics are based on robust standard errors adjusted for two-way clustering by firm and calendar month (Petersen 2009). ${ }^{* * *}, * *$, and $* *$ denote significance at the $0.01,0.05$, and 0.10 level respectively. 
Table 5

Multivariate analysis of the association between $\mathrm{V} / \mathrm{P}$ ratios and insider trading activity Dependent variable:

\begin{tabular}{|c|c|c|c|c|c|c|}
\hline & \multicolumn{6}{|l|}{ Dependent variable: } \\
\hline & $V P$ & $B U Y$ & SELL & $V P$ & $B U Y$ & SELL \\
\hline & Model 1 (OLS) & Model 2 (Logit) & Model 3 (Logit) & $\begin{array}{r}\text { Model } 4 \text { (OLS) } \\
\text { Smaller firms }\end{array}$ & $\begin{array}{r}\text { Model } 5 \text { (Logit) } \\
\text { Smaller firms }\end{array}$ & $\begin{array}{r}\text { Model } 6 \text { (Logit) } \\
\text { Smaller firms }\end{array}$ \\
\hline \multicolumn{7}{|l|}{ Test variables } \\
\hline \multirow[t]{2}{*}{$B U Y$} & 0.146 & & & 0.172 & & \\
\hline & {$[2.85] * * *$} & & & {$[2.95]^{* * *}$} & & \\
\hline \multirow[t]{2}{*}{ SELL } & -0.055 & & & -0.097 & & \\
\hline & {$[1.72]^{*}$} & & & {$[2.54]^{* *}$} & & \\
\hline \multirow[t]{2}{*}{$V P Q$} & & 0.199 & -0.040 & & 0.176 & -0.107 \\
\hline & & {$[2.74]^{* * *}$} & {$[0.47]$} & & {$[2.15]^{* *}$} & [1.28] \\
\hline \multicolumn{7}{|c|}{$\underline{\text { Control variables }}$} \\
\hline \multirow[t]{2}{*}{ SIZEQ } & -0.168 & 0.055 & 0.220 & -0.121 & 0.087 & 0.375 \\
\hline & {$[5.94] * * *$} & {$[0.55]$} & {$[1.88]^{*}$} & {$[4.22]^{* * *}$} & {$[0.77]$} & {$[3.36]^{* * *}$} \\
\hline \multirow[t]{2}{*}{$B P Q$} & -0.014 & 0.035 & -0.196 & -0.035 & -0.004 & -0.346 \\
\hline & {$[0.59]$} & {$[0.40]$} & {$[2.27]^{* *}$} & {$[1.43]$} & {$[0.04]$} & {$[3.48]^{* * *}$} \\
\hline \multirow[t]{2}{*}{ BHRPRE } & -0.103 & 0.042 & 0.558 & -0.130 & -0.007 & 0.473 \\
\hline & {$[2.26]^{* *}$} & {$[0.17]$} & {$[3.48] * * *$} & {$[2.60]^{* * *}$} & {$[0.03]$} & {$[2.60]^{* * *}$} \\
\hline \multirow[t]{2}{*}{$L E V$} & 1.318 & 0.949 & -0.089 & 1.453 & 1.187 & -0.395 \\
\hline & {$[7.50]^{* * *}$} & {$[1.64]$} & {$[0.14]$} & {$[7.35]^{* * *}$} & {$[1.76]^{*}$} & [0.61] \\
\hline \multirow[t]{2}{*}{$\ln (N U M E S T)$} & 0.023 & 0.085 & 0.043 & -0.003 & 0.011 & 0.091 \\
\hline & {$[0.45]$} & {$[0.48]$} & {$[0.21]$} & {$[0.05]$} & {$[0.05]$} & [0.42] \\
\hline \multirow[t]{2}{*}{$\ln (D I S P)$} & 0.139 & 0.286 & 0.034 & 0.200 & 0.407 & 0.267 \\
\hline & {$[0.73]$} & [0.49] & {$[0.05]$} & [1.03] & {$[0.71]$} & [0.36] \\
\hline \multirow[t]{2}{*}{ BETA } & 0.012 & -0.039 & 0.321 & 0.012 & -0.103 & 0.160 \\
\hline & {$[0.16]$} & [0.19] & [1.16] & {$[0.16]$} & {$[0.48]$} & [0.56] \\
\hline \multirow[t]{2}{*}{$I D V O L$} & -2.048 & 1.364 & -5.034 & -2.022 & 1.409 & -4.364 \\
\hline & {$[2.10]^{* *}$} & [0.32] & [1.17] & {$[1.99]^{* *}$} & {$[0.31]$} & [1.07] \\
\hline
\end{tabular}


Table 5 - cont'd

\begin{tabular}{|c|c|c|c|c|c|c|}
\hline \multirow[t]{2}{*}{ LOSS } & -0.555 & -0.521 & -0.967 & -0.545 & -0.587 & -0.996 \\
\hline & {$[5.03]^{* * *}$} & {$[1.54]$} & {$[3.68]^{* * *}$} & {$[4.68]^{* * *}$} & {$[1.48]$} & {$[3.58]^{* * *}$} \\
\hline \multirow[t]{2}{*}{$R N D$} & 0.014 & 0.465 & 0.082 & 0.029 & 0.495 & 0.059 \\
\hline & {$[0.20]$} & {$[2.29]^{* *}$} & {$[0.30]$} & {$[0.35]$} & {$[2.25]^{* *}$} & [0.24] \\
\hline Year dummies & Included & Included & Included & Included & Included & Included \\
\hline Month dummies & Included & Included & Included & Included & Included & Included \\
\hline $\mathrm{n}$ & 9,441 & 9,441 & 9,441 & 7,559 & 7,559 & 7,559 \\
\hline Adjusted $\mathrm{R}^{2}$ & 0.269 & & & 0.263 & & \\
\hline Wald $\chi^{2}$ & & $104.27 * * *$ & $321.24 * * *$ & & $92.06 * * *$ & $273.59 * * *$ \\
\hline Pseudo R ${ }^{2}$ & & 0.0506 & 0.0793 & & 0.0539 & 0.0987 \\
\hline
\end{tabular}


Table 6

Future returns analyses

\begin{tabular}{|c|c|c|c|c|}
\hline & $\begin{array}{c}\text { Dependent variable: } \\
\text { BHAR6m }\end{array}$ & BHAR6m & BHAR $12 m$ & BHAR $12 m$ \\
\hline & Model 1 & Model 2 & Model 3 & Model 4 \\
\hline \multicolumn{5}{|l|}{ Test variables } \\
\hline \multirow{2}{*}{$B U Y$} & 0.075 & 0.071 & 0.073 & 0.066 \\
\hline & {$[3.13]^{* * *}$} & {$[3.04] * * *$} & {$[2.43]^{* *}$} & {$[2.24]^{* *}$} \\
\hline \multirow[t]{2}{*}{ SELL } & 0.006 & 0.007 & 0.005 & 0.007 \\
\hline & {$[0.48]$} & {$[0.58]$} & {$[0.23]$} & [0.34] \\
\hline \multirow[t]{2}{*}{$V P Q$} & & 0.014 & & 0.024 \\
\hline & & {$[3.09]^{* * *}$} & & {$[3.06]^{* * *}$} \\
\hline \multicolumn{5}{|l|}{$\underline{\text { Control variables }}$} \\
\hline \multirow[t]{2}{*}{ SIZEQ } & 0.008 & 0.013 & 0.006 & 0.015 \\
\hline & [1.12] & {$[1.86]^{*}$} & {$[0.49]$} & [1.13] \\
\hline \multirow[t]{2}{*}{$B P Q$} & 0.014 & 0.014 & 0.030 & 0.030 \\
\hline & {$[2.83]^{* * *}$} & {$[2.90] * * *$} & {$[3.72] * * *$} & {$[3.84]^{* * *}$} \\
\hline \multirow[t]{2}{*}{ BHRPRE } & 0.045 & 0.045 & 0.077 & 0.077 \\
\hline & {$[2.64]^{* * *}$} & {$[2.64] * * *$} & {$[2.73]^{* * *}$} & {$[2.73]^{* * *}$} \\
\hline \multirow[t]{2}{*}{$L E V$} & -0.016 & -0.053 & -0.005 & -0.068 \\
\hline & {$[0.40]$} & [1.32] & {$[0.06]$} & [0.84] \\
\hline \multirow[t]{2}{*}{$\ln (N U M E S T)$} & 0.006 & 0.007 & 0.038 & 0.039 \\
\hline & {$[0.43]$} & {$[0.47]$} & {$[1.46]$} & [1.53] \\
\hline \multirow[t]{2}{*}{$\ln (D I S P)$} & -0.128 & -0.132 & -0.194 & -0.201 \\
\hline & {$[2.62] * * *$} & {$[2.73]^{* * *}$} & {$[2.21] * *$} & {$[2.32]^{* *}$} \\
\hline \multirow[t]{2}{*}{ BETA } & -0.035 & -0.037 & -0.056 & -0.060 \\
\hline & {$[2.09]^{* *}$} & {$[2.25]^{* *}$} & {$[2.07]^{* *}$} & {$[2.24]^{* *}$} \\
\hline \multirow[t]{2}{*}{$I D V O L$} & -0.084 & 0.003 & -0.204 & -0.059 \\
\hline & {$[0.35]$} & [0.01] & {$[0.47]$} & [0.13] \\
\hline \multirow[t]{2}{*}{ LOSS } & -0.026 & -0.015 & -0.051 & -0.032 \\
\hline & {$[1.25]$} & {$[0.71]$} & [1.35] & [0.88] \\
\hline \multirow[t]{2}{*}{$R N D$} & 0.014 & 0.016 & 0.004 & 0.008 \\
\hline & [0.77] & [0.89] & {$[0.14]$} & [0.25] \\
\hline \multirow[t]{2}{*}{$I N V P R Q$} & 0.021 & 0.020 & 0.040 & 0.038 \\
\hline & {$[4.72]^{* * *}$} & {$[4.60]^{* * *}$} & {$[4.40]^{* * *}$} & {$[4.29]^{* * *}$} \\
\hline Year dummies & Included & Included & Included & Included \\
\hline Month dummies & Included & Included & Included & Included \\
\hline $\mathrm{n}$ & 9,441 & 9,441 & 9,441 & 9,441 \\
\hline Adjusted $\mathrm{R}^{2}$ & 0.042 & 0.047 & 0.063 & 0.070 \\
\hline $\begin{array}{l}\text { OLS regressions } \\
\text { firm characteristi } \\
V P Q \text { which is th } \\
B P \text {; and } I N V P R Q \\
\text { errors adjusted } \\
\text { significance at th }\end{array}$ & $\begin{array}{l}\text {-adjusted stock retu } \\
(V P) \text {. All variables } \\
2 \text { which is the quinti } \\
\text { of the inverse of st } \\
\text { firm and calendar } \\
\text { espectively. }\end{array}$ & $\begin{array}{l}\mathrm{s}(B H A R) \mathrm{c} \\
\text { re defined } \\
\text { rank of } S I Z \\
\text { k price. } \mathrm{t}-\mathrm{s} \\
\text { onth (Peter }\end{array}$ & $\begin{array}{l}\text { ler trading ir } \\
\text { e notes to T } \\
Q \text { which is th } \\
\text { are based o } \\
09 \text { ). ***,* }\end{array}$ & $\begin{array}{l}\text { r variables, } \\
\text { except for } \\
\text { tile rank of } \\
\text { ist standard } \\
* * \text { denote }\end{array}$ \\
\hline
\end{tabular}


Table 7

Future returns analyses: Smaller firms

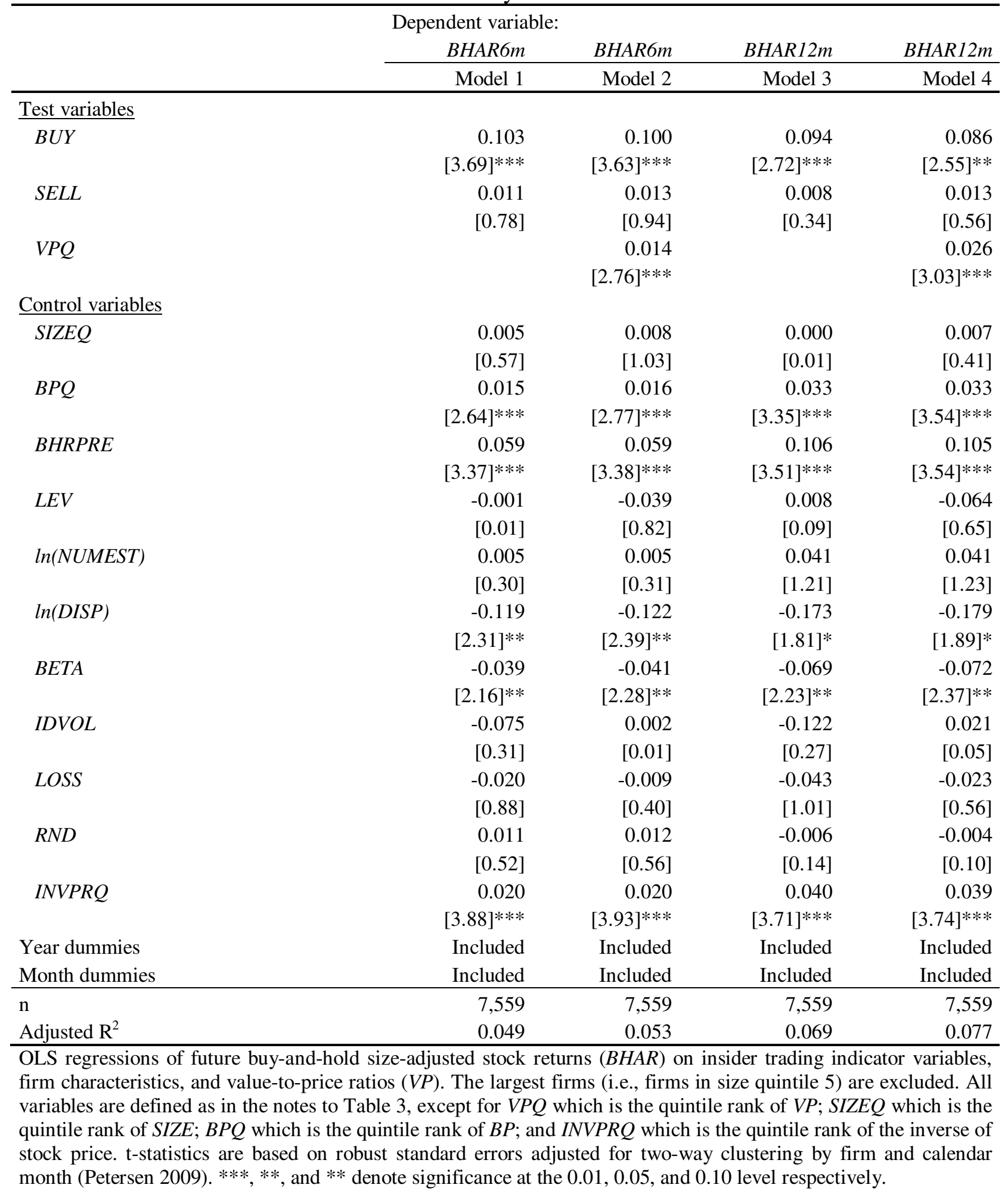


Table 8

Robustness test: Summary statistics on firm-specific time series regressions

\begin{tabular}{|c|c|c|c|c|}
\hline & \multicolumn{4}{|c|}{ Dependent variable: } \\
\hline & $V P$ & $V P$ & BHAR $12 \mathrm{~m}$ & BHAR $12 m$ \\
\hline & Model 1 & $\begin{array}{r}\text { Model } 2 \\
\text { Smaller firms } \\
\end{array}$ & Model 3 & $\begin{array}{r}\text { Model } 4 \\
\text { Smaller firms } \\
\end{array}$ \\
\hline \multirow[t]{3}{*}{$B U Y$} & 0.191 & 0.203 & 0.062 & 0.076 \\
\hline & {$[3.02]^{* * *}$} & {$[2.75]^{* * *}$} & {$[2.60] * *$} & {$[2.82] * * *$} \\
\hline & $(42: 21)$ & $(35: 16)$ & $(41: 22)$ & $(36: 15)$ \\
\hline \multirow[t]{3}{*}{ SELL } & -0.054 & -0.051 & -0.037 & -0.015 \\
\hline & {$[1.42]$} & [1.14] & {$[1.87]^{*}$} & [0.75] \\
\hline & $(28: 36)$ & $(25: 26)$ & $(26: 38)$ & $(24: 27)$ \\
\hline \multirow[t]{3}{*}{$V P Q$} & & & 0.039 & 0.038 \\
\hline & & & {$[3.54] * * *$} & {$[2.94]^{* * *}$} \\
\hline & & & $(50: 23)$ & $(43: 18)$ \\
\hline n (firm-months) & 7,050 & 5,419 & 7,050 & 5,419 \\
\hline n (firm-regressions) & 75 & 63 & 75 & 63 \\
\hline Adjusted $\mathrm{R}^{2}$ (average) & 0.228 & 0.227 & 0.081 & 0.091 \\
\hline
\end{tabular}

Summary statistics on firm-specific time series OLS regressions of $V P$ on insider trading indicators in models 1 and 2 , and regressions of BHAR $12 \mathrm{~m}$ on insider trading indicators and the quintile rank of $V P$ in models 3 and 4 . The sample is restricted to firms with at least one active insider trading (buy or sell) month and at least ten monthly $V P$ observations. t-statistics are presented in brackets below the average coefficients obtained from $\mathrm{n}$ firm-specific regressions. (aa:bb) below the t-statistic reflects the distribution of coefficient estimates, where aa indicates the number of positive estimates and bb indicates the number of negative estimates. "Smaller firms" are those firms not included in the top quintile of firm size (market value) based on monthly sorting. ***, **, and ** denote significance at the $0.01,0.05$, and 0.10 level respectively. 
Table 9

Robustness test: Abnormal Earnings Growth valuation

Panel A: Firm characteristics for quintile portfolios based on $V P \_A E G(\mathrm{n}=8,697)$

\begin{tabular}{lrrrrrrrr}
\hline & $\mathrm{Q} 1$ & $\mathrm{Q} 2$ & $\mathrm{Q} 3$ & $\mathrm{Q} 4$ & $\mathrm{Q} 5$ & $\mathrm{Q} 5-\mathrm{Q} 1$ & $\mathrm{t}-\mathrm{stat}$ & \\
\hline VP_AEG & -0.141 & 1.231 & 1.934 & 2.896 & 6.137 & 6.279 & 18.96 & $* * *$ \\
VP & 0.976 & 1.060 & 1.208 & 1.319 & 1.418 & 0.442 & 5.69 & $* * *$ \\
BUY & 0.028 & 0.032 & 0.024 & 0.023 & 0.035 & 0.007 & 0.80 & \\
SELL & 0.063 & 0.093 & 0.067 & 0.053 & 0.036 & -0.027 & -2.21 & $* *$ \\
SIZE & 6,501 & 4,132 & 2,193 & 1,353 & 1,168 & -5332.90 & -2.79 & $* * *$ \\
BP & 0.577 & 0.492 & 0.607 & 0.705 & 1.048 & 0.470 & 4.82 & $* * *$ \\
BHRPRE & 0.107 & 0.132 & 0.154 & 0.130 & 0.026 & -0.081 & -1.95 & $*$ \\
LEV & 0.588 & 0.620 & 0.624 & 0.617 & 0.604 & 0.016 & 0.56 & \\
NUMEST & 15.148 & 13.912 & 11.793 & 10.043 & 9.483 & -5.665 & -3.74 & $* * *$ \\
DISP & 0.197 & 0.133 & 0.145 & 0.176 & 0.263 & 0.066 & 1.74 & $*$ \\
BETA & 0.901 & 0.915 & 0.985 & 1.065 & 1.215 & 0.314 & 3.46 & $* * *$ \\
IDVOL & 0.085 & 0.083 & 0.087 & 0.090 & 0.106 & 0.021 & 3.77 & $* * *$ \\
LOSS & 0.040 & 0.025 & 0.041 & 0.068 & 0.200 & 0.161 & 5.25 & $* * *$ \\
RND & 0.259 & 0.214 & 0.160 & 0.136 & 0.180 & -0.079 & -1.28 & \\
BHAR6m & -0.012 & 0.000 & 0.010 & 0.021 & -0.009 & 0.003 & 0.16 & \\
BHARI2m & -0.014 & 0.005 & 0.018 & 0.023 & -0.008 & 0.006 & 0.21 & \\
\hline & & & & & & & &
\end{tabular}

Panel B: Association between insider trading and mispricing based on $V P \_A E G$ versus $V P$

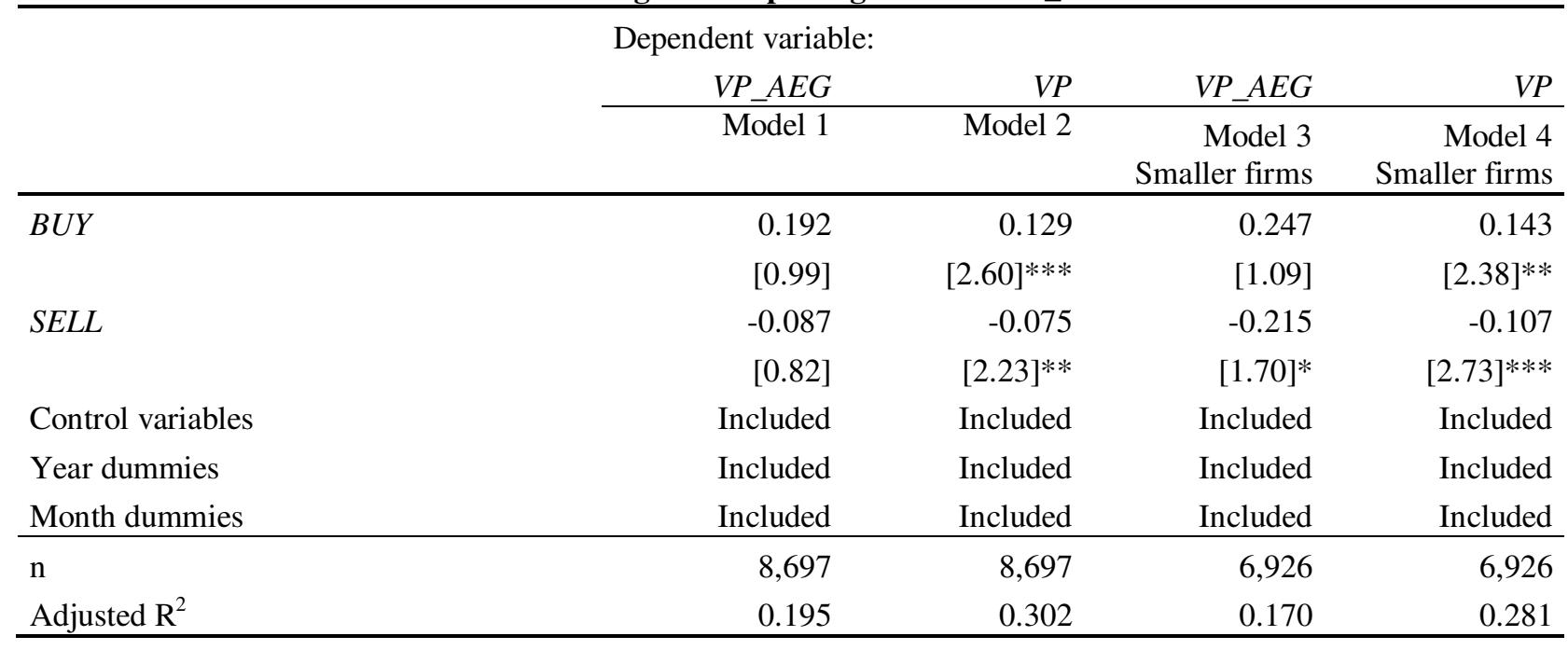


Panel C: Future abnormal returns tests using $V P \_A E G$ as proxy for mispricing

Dependent variable:

\begin{tabular}{rrrr} 
BHAR $12 m$ & BHAR $12 m$ & BHAR $12 m$ & BHAR $12 m$ \\
\hline & & Model 3 & Model 4 \\
Model 1 & Model 2 & Smaller firms & Smaller firms \\
\hline
\end{tabular}

\begin{tabular}{|c|c|c|c|c|}
\hline \multicolumn{5}{|l|}{ Test variables } \\
\hline \multirow[t]{2}{*}{$B U Y$} & 0.072 & 0.067 & 0.101 & 0.095 \\
\hline & {$[2.39]^{* *}$} & {$[2.25]^{* *}$} & {$[2.86]^{* * *}$} & {$[2.74] * * *$} \\
\hline \multirow[t]{2}{*}{ SELL } & 0.009 & 0.011 & 0.014 & 0.017 \\
\hline & {$[0.44]$} & {$[0.53]$} & [0.60] & {$[0.76]$} \\
\hline \multirow[t]{2}{*}{$V P \_A E G Q$} & 0.006 & 0.002 & 0.002 & -0.003 \\
\hline & [0.92] & {$[0.29]$} & [0.24] & {$[0.48]$} \\
\hline \multirow[t]{2}{*}{$V P Q$} & & 0.020 & & 0.023 \\
\hline & & {$[2.36]^{* *}$} & & {$[2.53]^{* *}$} \\
\hline Control variables & Included & Included & Included & Included \\
\hline Year dummies & Included & Included & Included & Included \\
\hline Month dummies & Included & Included & Included & Included \\
\hline$\overline{\mathrm{n}}$ & 8,697 & 8,697 & 6,926 & 6,926 \\
\hline Adjusted $\mathrm{R}^{2}$ & 0.070 & 0.074 & 0.084 & 0.089 \\
\hline
\end{tabular}

In Panel $\mathrm{A}$, observations are sorted into quintile portfolios based on the magnitude of $V P \_A E G$ in every calendar month, where VP_AEG is the value-to-price ratio based on the Abnormal Earnings Growth valuation model. Panel B presents OLS regressions of value-to-price ratios $\left(V P \_A E G\right.$ or $\left.V P\right)$ on insider trading indicator variables and firm characteristics. "Smaller firms" are those firms not included in the top quintile of firm size (market value) based on monthly sorting. Panel C presents OLS regressions of future buy-and-hold size-adjusted stock returns (BHARI2m) on insider trading indicator variables, firm characteristics, and the monthly quintile rank of AEG based value-to-price ratios $\left(V P \_A E G Q\right)$. Variables are defined as in the notes to Table 3. t-statistics are based on robust standard errors adjusted for two-way clustering by firm and calendar month (Petersen 2009). ***, **, and ** denote significance at the $0.01,0.05$, and 0.10 level respectively. 